\title{
Spillover Effects of Marketing in Mutual Fund Families*
}

\author{
Joop Huij and Marno Verbeek ${ }^{\dagger}$
}

This version: February 26, 2007

\begin{abstract}
This paper investigates the presence of spillover effects of marketing in mutual fund families. We find that funds with high marketing expenses generate spillovers, and enhance cash inflows to family members with low marketing expenses. In particular, low-marketing funds that are operated by a family with high marketing expenses have substantially larger inflows after positive returns than otherwise similar funds that are operated by a family with low marketing expenses, while they have smaller outflows after negative returns. One way to interpret the spillovers is that they are a by-product of individual fund marketing whereby the entire family is made more visible to investors. An alternative explanation of this observation is that funds with low marketing expenses are directly subsidized by family members with high marketing expenses. We develop and perform a set of tests to evaluate these two alternative hypotheses. The results of all tests support the subsidization hypothesis, and suggest that at least part of the spillovers can be attributed to favoritism. These results suggest that conflicts of interest between investors and fund families have been exacerbated by competition in the mutual fund industry.
\end{abstract}

JEL classifications: G11, G14, G19

Keywords: Mutual fund flows, marketing, cross-subsidization, favoritism

\footnotetext{
${ }^{*}$ We are grateful to Robin Braun, Jeroen Derwall, Miles Livingston, Henri Serveas, and seminar participants at Maastricht University for helpful comments. We especially thank Nick Bollen for helpful suggestions that greatly improved the paper. We also gratefully acknowledge financial support from Erasmus Research Institute of Management, Netherlands Organization for Scientific Research, and Trustfund Erasmus University Rotterdam. We welcome comments, including references to related papers we have inadvertently overlooked.

${ }^{\dagger}$ Huij and Verbeek are at RSM Erasmus University. Corresponding author is Huij. Email addresses are jhuij@rsm.nl and mverbeek@rsm.nl. The usual disclaimer applies.
} 


\title{
Spillover Effects of Marketing in Mutual Fund Families
}

\author{
This version: February 26, 2007
}

\begin{abstract}
This paper investigates the presence of spillover effects of marketing in mutual fund families. We find that funds with high marketing expenses generate spillovers, and enhance cash inflows to family members with low marketing expenses. In particular, low-marketing funds that are operated by a family with high marketing expenses have substantially larger inflows after positive returns than otherwise similar funds that are operated by a family with low marketing expenses, while they have smaller outflows after negative returns. One way to interpret the spillovers is that they are a by-product of individual fund marketing whereby the entire family is made more visible to investors. An alternative explanation of this observation is that funds with low marketing expenses are directly subsidized by family members with high marketing expenses. We develop and perform a set of tests to evaluate these two alternative hypotheses. The results of all tests support the subsidization hypothesis, and suggest that at least part of the spillovers can be attributed to favoritism. These results suggest that conflicts of interest between investors and fund families have been exacerbated by competition in the mutual fund industry.
\end{abstract}

JEL classifications: G11, G14, G19

Keywords: Mutual fund flows, marketing, cross-subsidization, favoritism 


\section{Introduction}

When we consider the mutual fund industry over the past decade, one of the most notable developments is the enormous growth of funds that are operated by fund families. While almost 20 percent of all US equity funds were offered as stand-alone in 1992, this figure rapidly declined to less than 4 percent by the end of 2002. Plausible reasons for this phenomenon are the competitive advantages that family membership brings along, such as economies of scale. In addition, recent studies document substantial spillover effects between funds in a family. For example, several authors report spillovers in fund performance.

Past performance is one of the most important determinants of investors' cash flows to funds (see e.g., Gruber (1996), Sirri and Tufano (1998), Chevalier and Ellison (1999), and Del Guercio and Tkac (2002)). Funds with strong track records are rewarded with large cash flows into the funds, while losers are not disciplined with equally large outflows. However, Ivkovic (2001) and Nanda et al. (2004) report that cash flows are not only affected by a fund's own performance, but also by the performance of other funds in the family. Stellar performance of a fund generates substantial spillovers in the sense that cash inflows to other funds in the family are above and beyond what one would expect given the funds' own performance. On the other hand, poor performance of a fund does not seem to result in abnormal cash outflows from its family members. Consistent with these findings, Khorana and Servaes (2005) find that the presence of a star fund in a family has a positive effect on the family's market share. Other spillover effects have been documented by Zhao (2004), who finds evidence that fund families that signal superior performance by closing a star fund to new investments enjoy higher cash inflows into the rest of the family.

There are several possible explanations for this behavior: investors might believe that the performance of an individual fund conveys information about the quality of the family to which the fund belongs, e.g., quality of research, or monitoring activities of fund managers. Another reason is that funds with extreme performance typically receive more media attention, thereby making the family to which the fund belongs more visible to investors 
(Sirri and Tufano, 1998).

Goetzmann and Ibbotson (1993) and Nanda et al. (2004) argue that fund families are well aware of these spillover effects, and anticipate investor behavior to maximize cash flows into their funds. Families that manage many funds with large cross-sectional dispersion in performance are more likely to generate a star, and attract larger cash flows in the funds. Moreover, Nanda et al. (2004) assert that this mechanism especially induces lower ability families to pursue this type of strategy.

In this study we investigate the presence of spillover effects of marketing in fund families. It is abundantly clear that fund management companies consider marketing to be an important method to attract new investors. In the sample we use in this study, US equity funds spent more than 9 billion dollars on marketing and distribution activities in 2003; an amount that is more than 0.4 percent of their total net assets under management over the year. For comparison, all operating expenses summed together (including management fees) amount to less than one percent of total net assets under management. ${ }^{1}$ Several authors confirm that marketing is an effective method for funds to garner new money. Jain and $\mathrm{Wu}(2000)$ find that funds that are advertised in Barron's or Money magazine attract significantly larger cash flows in comparison to other funds, even though these funds do not exhibit superior performance. Sirri and Tufano (1998) document that funds with higher fees (and presumably higher marketing expenses) receive larger cash inflows as a response to their performance than funds with lower fees. Consistent with these findings, Barber et al. (2005) report a positive relation between funds' marketing expenses and subsequent inflows, especially when these expenses are less salient to investors. More recently, a few studies have examined the impact of marketing on cash flows at the aggregate familylevel. Gallaher et al. (2006) report that fund families with the highest levels of advertising receive greater cash inflows, but the authors do not find that advertising affects the flowperformance relation at the family-level. Further, Khorana and Servaes (2005) examine the relation between marketing expenses and family market share, and find that there is a positive relation for small families.

However, none of these studies has investigated the impact of fund marketing on in- 
vestor flows to other funds in the family. For example, do high-marketing funds generate spillovers, and enhance cash inflows to low-marketing funds in the family? To investigate the presence of such intrafamily marketing spillovers, we employ a regression-based methodology investigating cash flows of US equity funds that are operated within a fund family. In particular, we test whether the flow-performance relationship is affected by marketing and distribution expenses at the individual fund and fund family level. Analyzing data over the period 1992-2003, we address the following questions. First, do high-marketing funds have a stronger flow-performance relation than low-marketing funds, and how is this affected by fund age and size? Second, do cash flows respond differently to past performance when a fund is operated in a family that has high-marketing expenses?

The main conclusions of our study can be summarized as follows. First, we find that funds with high marketing expenses draw substantially larger inflows as a response to their performance. More specifically, cash inflows following positive returns are almost twice as large for high-marketing funds compared to low-marketing funds. On the other hand, on the other hand, cash outflows following negative returns are only marginally larger for highmarketing funds compared to low-marketing funds. These results provide further evidence that mutual fund marketing is very effective in making good performance more visible to investors. Second, we find that small and young funds with low marketing expenses that are operated by a family with high marketing expenses have substantially larger inflows after positive returns than otherwise similar funds that are operated by a family with low marketing expenses. Furthermore, these funds appear to have smaller outflows following negative returns. These results indicate that high-marketing families provide favorable conditions to incubate new funds. Given the findings of Khorana and Servaes (2005) that families that start more funds have higher market share, one might expect high-marketing families to have a considerable competitive advantage over low-marketing families.

One way to interpret the spillovers is that they are a by-product of individual fund marketing whereby the entire family is made more visible to investors. An alternative explanation of this observation is that funds with low marketing expenses are directly subsidized by family members with high marketing expenses. A family could pay for 
marketing of a particular fund through expenses allocated to other funds. We develop and perform a set of tests to evaluate the alternative hypotheses. The results of all tests support the subsidization hypothesis and suggest that at least part of the spillovers can be attributed to families favoring some funds by transferring marketing exposure across member funds. These results suggest that conflicts of interest between investors and fund families have been exacerbated by competition in the mutual fund industry.

\section{Data}

\section{A Sources and fund selection}

Our primary data are from the 2003 Mutual Fund Survivorship-bias Free Database compiled by the Center for Research in Security Prices (CRSP). This database covers returns, supplemental data, and fund classifications on all US open-end mutual funds, including defunct funds. Since CRSP basically includes all funds that existed during this period, our data are free of survivorship-bias as documented by Brown et al. (1992) and Brown and Goetzmann (1995). We extract data on returns, total net assets, family membership, and marketing and distribution expenses for all diversified US equity funds over the period January 1992 to December 2003. The return data come in monthly frequency. Data on the funds' total net assets, family membership, and marketing and distribution expenses come in yearly frequency. We follow a procedure similar to Pastor and Stambaugh $(2002 \mathrm{~b}, \mathrm{a})$ and Huij and Verbeek (2007) and use the additional information CRSP provides on fund classifications, expenses, and load data to construct a sample of diversified US equity funds. We exclude funds with no classification, expense, or load data in the annual summary at the end of each previous year. Additionally, we examine fund classifications at the end of each previous year, and exclude flexible funds, bond funds, mortgage-backed funds, multimanager funds, money market funds, balanced funds, funds that invest in precious metals, and international funds. From the remaining funds, we select funds that are classified as small/cap growth, growth, growth \& income, or income fund. Finally, we drop funds with less than two calendar years of consecutive returns over the entire sample period. 


\section{B Measurement of performance, investor flows, and marketing and distribution expenses}

For the main tests in our analyses, we investigate the impact of mutual fund marketing on the relation between investor flows and past performance. The definitions of most variables (i.e., investor flows and performance), and the regression methodology we use to investigate the flow-performance relation are standard in this stream of literature. The main innovation of our study is that we investigate the interaction of fund marketing with cash flows to other funds in the family. In particular, we investigate whether high-marketing funds generate spillovers, and enhance cash inflows to low-marketing funds in the family. Below we describe how we measure fund performance, investor flows, and marketing and distribution expenses.

Consistent with most of the literature, we take each fund's cumulative total return over year $t$ as a measure for fund performance:

$$
C T R_{i, t}=\left[\left(1+r_{i, t, 1}\right) \cdot\left(1+r_{i, t, 2}\right) \cdot \ldots \cdot\left(1+r_{i, t, 12}\right)\right]-1
$$

where $r_{i, t, j}$ is fund $i$ 's total return (change in net asset value plus distribution) over month $j$ in year $t$.

To compute the dollar flow of fund $i$ in year $t$, we follow the approach advocated by among others Sirri and Tufano (1998), Zheng (1999), and Del Guercio and Tkac (2002):

$$
D F_{i, t}=\left[T N A_{i, t}-T N A_{i, t-1} \cdot\left(1+C T R_{i, t}\right)\right]
$$

where $T N A_{i, t}$ denotes the total net assets under management of fund $i$ at the end of year $t$. We then normalize the dollar flows by the funds' total net assets under management to obtain a measure for the funds' percentage flows, i.e., $F_{i, t}=D F_{i, t} / T N A_{i, t-1}$. We remove observations of fund flows below -90 percent and above 1,000 percent. As pointed out by Bollen (2006), these observations are likely to be the results of misplacement of the decimal point. The resulting sample holds 2,200 funds in the average year, ranging from 714 funds in 1993 to 4,199 funds in 2002. In total, the sample covers 22,004 fund-years. 
Marketing and distribution expenses are measured by the funds' front-end load fees and $12 \mathrm{~b} 1$ fees. Front-end load fees are upfront sales commissions paid by investors when entering a fund, and are used to cover marketing related costs such as compensation for broker-dealer sales professionals, advertising, and other sales-promotion activities. While $12 \mathrm{~b} 1$ fees are used for virtually the same purposes, these fees are paid periodically by the funds out of their assets, rather than directly by the investors. Barber et al. (2005) argue that $12 \mathrm{~b} 1$ fees could therefore be expected to be less salient than front-end load fees, and more effective to attract new investors. Further, given the results of Nanda et al. (2006) that $12 \mathrm{~b} 1$ funds cater a more myopic investor clientele, investors in these type of funds are likely to respond more strongly to marketing and distribution activities. Another difference between front-end load fees and $12 \mathrm{~b} 1$ fees is that $12 \mathrm{~b} 1$ fees are explicitly earmarked for marketing and distribution activities. For example, amounts spent under 12b1 plans and the reasons for these expenses must be be approved by the funds' directors. Shareholders must also approve increases in a fund's $12 \mathrm{~b} 1$ fee. As a measure of fund $i$ 's total marketing expenses in year $t\left(T X_{i, t}\right)$ we take the fund's reported $12 \mathrm{~b} 1$ fee $\left(12 B 1_{i, t}\right)$ plus one-seventh of the fund's front-end load fee $\left(L O A D_{i, t}\right)$. Consistent with most of the literature, we hereby assume that the average holding period of a load-fund is seven years, see. e.g., Sirri and Tufano (1998), Barber et al. (2005), and Khorana and Servaes (2005).

Next, we compute performance, investor flows, and marketing and distribution expenses at the aggregate family level. We measure the performance of family $f$ in year $t$ as the value-weighted average cumulative total return of all funds in the family:

$$
C T R_{f, t}=\frac{\sum_{i} C T R_{i, t} \cdot T N A_{i, t}}{\sum_{i} T N A_{i, t}}
$$

where the summation is over all funds in family $f$. Percentage flows to family $f$ in year $t$ are computed as the dollar flows of all funds in the family as a percentage of the family's lagged total net asset under management:

$$
F_{f, t}=\frac{\sum_{i} D F_{i, t}}{\sum_{i} T N A_{i, t-1}} .
$$

Finally, we compute the average front-end load fee charged by family $f$ for each dollar 
under management over year $t$ as

$$
L O A D_{f, t}=\frac{\sum_{i} L O A D_{i, t} \cdot T N A_{i, t}}{\sum_{i} T N A_{i, t}} .
$$

Similarly, we compute the average 12b1-fee charged by family $f$ for each dollar under management over year $t\left(12 B 1_{f, t}\right)$. As a measure of the total marketing expenses of family $f$ over year $t\left(T X_{f, t}\right)$, we take $12 B 1_{f, t}$ plus one-seventh of $L O A D_{f, t}$.

The relation between investor flows and performance, and the impact of mutual fund marketing on this relation, is modeled using the regression framework described in next section.

\section{Growth of fund families and marketing and distribution ex- penses}

The two most notable developments in the mutual fund industry over the past decade are the growth of fund families, and the enormous increase in the the dollar amount spend on marketing and distribution activities. In Figures 1, 2, and 3 we portray both developments. Figure 1 presents the number of diversified US equity funds in our sample over the period 1993 to 2003. From the 714 funds that were available in 1993, 141 funds were offered as stand-alone fund. While the number of stand-alone funds remains more or less constant over time, the total number of funds increases to 4,199 in 2002. Thus, while about 20 percent of the funds in 1993 were offered as stand-alone fund, this figure rapidly declined to less than 4 percent by the end of 2002. In Figure 2 we present a graph with the number of equity fund families (i.e., families that consist of at least two diversified US equity funds) and the average number of funds per family in our sample over the period 1993 to 2003. Where the number of equity fund families increased from 139 in 1993 to 283 in 2002, the average number of fund per family increased from 5.14 in 1993 to 14.84 in 2002.

Figure 3 presents an estimate of the dollar amount spent on mutual fund marketing and distribution over the period 1993 to 2003. In addition, the graph presents marketing and distribution expenses as a percentage of total net assets under management. Several interesting patterns show up. First, we observe an enormous increase in the dollar amount 
spent on marketing and distribution; while slightly more than $\$ 1.6$ billion was spent on marketing and distribution activities in 1993, this amount increased to more than $\$ 9.2$ billion in 2002. Second, it appears that the portion of marketing and distribution activities that is financed by $12 \mathrm{~b} 1$ fees has grown substantially over time. In 1993, less than 25 percent of the marketing and distribution activities were financed by $12 \mathrm{~b} 1$ fees. However, in 2002 this number was almost 50 percent. Finally, the dollar amount spent on marketing and distribution activities has five folded, whereas marketing and distribution expenses as percentage of total net assets have decreased over time. While 0.51 percent on total-netassets under management was spent on marketing in 1993, this number decreased to 0.42 percent in 2002 .

\section{The impact of fund marketing on the flow- performance relation}

In our first analysis, we investigate whether high-marketing funds experience differential inand outflows in response to their performance versus low-marketing funds. We concentrate on family-operated funds (i.e., funds that have at least one family member), and drop all stand-alone funds. The resulting sample comprises 2,054 funds in the average year, ranging from 573 funds in 1993 to 4,043 funds in 2002. In total, the sample covers 20,542 fund-years.

While there is no consensus in the literature on how to specify the fund flow-performance relation, most researchers employ a non-linear model specification. ${ }^{2}$ Sirri and Tufano (1998) perform piecewise linear regressions of investor flows on the funds' fractional ranks based on one-year raw returns; Barber et al. (2005) include squared returns in their regression of investor flows on funds' returns; and Bollen (2006) employs an interaction variable to capture potential asymmetries in the relation between investor flows and fund returns. We run regressions in spirit similar to Bollen (2006) and estimate the following model using 
ordinary-least-squares (OLS):

$$
\begin{array}{r}
F_{i, t+1}=\left(b_{0}+b_{1} \cdot \operatorname{HIGHTX}_{i, t}+b_{2} \cdot I_{i, t}+b_{3} \cdot \operatorname{HIGHTX}_{i, t} \cdot I_{i, t}\right) \cdot C T R_{i, t}+ \\
a_{0, t}+a_{1, t} \cdot \operatorname{HIGHTX}_{i, t}+\epsilon_{i, t},
\end{array}
$$

where $\operatorname{HIGHT} X_{i, t}$ is a dummy variable that indicates whether fund $i$ is a high-marketing fund over year $t$. The dummy equals one if the fund's marketing and distribution expenses are greater than the median, and zero otherwise. Further, $I_{i, t}$ is an indicator variable that equals one if fund $i$ 's return over year $t$ is negative, and zero otherwise. The regression model includes year dummies to capture year-specific effects. As explained by Bollen (2006), the coefficients in this regression model can be interpreted as follows:

$b_{0}$ : $\quad$ Percentage flow to low-marketing funds for every one percent increase in prior year return when returns are positive

$b_{0}+b_{1}: \quad$ Percentage flow to high-marketing funds for every one percent increase in prior year return when returns are positive

$b_{0}+b_{2}$ : $\quad$ Percentage flow to low-marketing funds for every one percent increase in prior year return when returns are negative

$b_{0}+b_{1}+b_{2}+b_{3}: \quad$ Percentage flow to high-marketing funds for every one percent increase in prior year return when returns are negative

To ensure that the results are not driven by small or young funds it is recommended to control for fund size and age in model Eq. (6). Sirri and Tufano (1998) and Barber et al. (2005) include the natural logarithms of the funds' lagged total net assets and age as control variables; Barber et al. (2005) and Bollen (2006) perform their analyses on subgroups of funds based on their size and age. Following these studies, we employ a model specification that extends our base model Eq. (6) with the natural logarithms of the funds' total net assets under management $\left(\ln \left(T N A_{i, t}\right)\right)$ and age $\left(\ln \left(A G E_{i, t}\right)\right)$ :

$$
\begin{array}{r}
F_{i, t+1}=\left(b_{0}+b_{1} \cdot \operatorname{HIGHTX}_{i, t}+b_{2} \cdot I_{i, t}+b_{3} \cdot \operatorname{HIGHTX}_{i, t} \cdot I_{i, t}\right) \cdot C T R_{i, t}+ \\
b_{4} \cdot \ln \left(T N A_{t}\right)+b_{5} \cdot \ln \left(A G E_{t}\right)+a_{0, t}+a_{1, t} \cdot \operatorname{HIGHTX}_{i, t}+\epsilon_{i, t},
\end{array}
$$

In addition, we run regressions Eq. (6) and Eq. (7) on the following subgroups of the funds: (i) funds with at least $\$ 15$ million of total-net-assets under management, (ii) funds 
with at least $\$ 100$ million of total net assets under management, (iii) funds that are at least 3 years old, and (iv) funds that are at least 5 years old. The results are presented in Table 1.

We first consider the results for the entire sample of funds. The coefficient estimate for $C T R_{i, t}$ is positive and highly significant, which indicates a strong relation between positive returns and future cash flows for low-marketing funds. The results in column $\mathrm{B}$ indicate that inflows to low-marketing funds increase with 1.05 percent for every one percent increase in prior year return when the return is positive.

Further, the coefficient estimate for $\operatorname{HIGHTX}_{i, t} \cdot C T R_{i, t}$ indicates that the differential inflows to high-marketing funds as a response to positive returns are significantly different from zero. The estimate in column B of 0.94 indicates that for every one percent increase in prior year return, inflows to high-marketing funds increase with 1.99 percent (1.05 percent plus 0.94 percent) when returns are positive. Thus, it appears that cash inflows following positive returns are almost twice as large for high-marketing funds compared to low-marketing funds.

In addition, we investigate investors' response to negative returns. The coefficient estimates for $C T R_{i, t} \cdot I_{i, t}$ and $\operatorname{HIGHTX}_{i, t} \cdot I_{i, t} \cdot C T R_{i, t}$ point to an asymmetric flowperformance relation for both low- and high-marketing funds. The estimates in column $\mathrm{B}$ indicate that outflows following negative returns increase by 0.96 percent $(1.05$ percent minus 0.09 percent) for every one percent decrease in prior year return for low-marketing funds, and by 1.18 percent (1.05 percent plus 0.94 percent minus 0.09 percent minus 0.72 percent) for high-marketing funds. Finally, the negative coefficient estimates for $\ln \left(T N A_{i, t}\right)$ and $\ln \left(A G E_{i, t}\right)$ indicate that small and young funds experience larger inflows than large and mature funds.

In Figure 4, we give a graphical representation of the estimated flow-performance relation for high- and low-marketing funds. The solid line draws the estimated relation between fund flow and lagged returns for high-marketing funds, and the dashed line draws this relation for low-marketing funds. The flows to high-marketing funds after positive returns are almost twice as large. While high-marketing funds also seem to experience somewhat larger 
outflows after negative returns, the outflows are substantially smaller than the inflows due to marketing.

When we consider the results for the subgroups of funds based on their total net assets or age in Table 1, we consistently observe that high-marketing funds have a much stronger flow-performance relation than low-marketing funds after positive returns. On the other hand, high-marketing funds also have somewhat larger outflows after negative returns. However, the outflows are substantially smaller than the inflows due to marketing.

In the analyses above, the models Eq. (6) and Eq. (7) are estimated using a pooled regression framework as in Bollen (2006). We also experiment with a cross-sectional regression framework, where we estimate regression Eq. (7) year-by-year for all funds, and average the regression coefficients using the Fama and MacBeth (1973) approach. ${ }^{3}$ The results are in Table 2, and are qualitatively very similar to those using the pooled regression framework. Given the relatively small number of years in our sample, and given that the number of available funds at the end of the sample period is several times larger than at the beginning, we believe that the pooled framework is preferred to the cross-sectional framework in this specific situation. Throughout the remainder of this study, we therefore employ pooled regressions.

In summary, our results indicate a direct positive relation between lagged fund performance and investor flows. This flow-performance relation is asymmetric in the sense that inflows after positive performance are larger than outflows after negative performance. More importantly, high-marketing funds attract substantially larger inflows as a response to their performance than do low-marketing funds. Our results provide strong evidence that mutual fund marketing is very effective in making positive returns more visible to investors. An additional interesting finding is that it appears that almost all asymmetry in the flow-performance relation reported in the literature is found for funds that have above median marketing and distribution expenses. When the relation between fund performance and investor flows is investigated for low-marketing funds, the relation is almost linear. 


\section{Spillover effects of marketing in mutual fund families}

Because all funds in our sample are family-operated, marketing expenses at the family level may also have an impact on the flow-performance relation of a given fund. To investigate this issue, we examine whether there is an interaction between the flow-performance relation of funds with low marketing expenses and membership of a family with high marketing expenses. To this end, we estimate the following regression for low-marketing funds in our sample (i.e., funds with total marketing expenses below the median):

$$
\begin{array}{r}
F_{i, t+1}=\left(b_{0}+b_{1} \cdot H I G H T X F_{i, t}+b_{2} \cdot I_{i, t}+b_{3} \cdot H I G H T X \_F_{i, t} \cdot I_{i, t}\right) \cdot C T R_{i, t}+ \\
a_{0, t}+a_{1, t} \cdot H I G H T X_{-} F_{i, t}+\epsilon_{i, t},
\end{array}
$$

where $H I G H T X_{-} F_{i, t}$ is a dummy variable indicating whether fund $i$ is member of a highmarketing family over year $t$. The dummy equals one if the fund is member of a family with marketing and distribution expenses that are greater than the median, and zero otherwise. In addition, we employ a model specification that extends regression model Eq. (8) with the natural logarithms of the funds' total net assets under management and age. We also perform subgroup analyses as in the previous section, and estimate the regressions for the following subsamples of funds: (i) low-marketing funds with at least $\$ 15$ million of total net assets under management, (ii) low-marketing funds with at least $\$ 100$ million of total net assets under management, (iii) low-marketing funds that are at least 3 years old, and (iv) low-marketing funds that are at least 5 years old. The regression results are in Table 3.

The coefficient estimates for $\operatorname{HIHTX}_{-} F_{i, t} \cdot C T R_{i, t}$ and $\operatorname{HIGHTX}_{-} F_{i, t} \cdot I_{i, t} \cdot C T R_{i, t}$ capture the differential flows to low-marketing funds that are member of a high-marketing family versus low-marketing funds that are member of a low-marketing family. The results for the entire sample of low-marketing funds in columns A and B indicate significant positive differential inflows after positive returns, and significant negative differential outflows after negative returns. Low-marketing funds that are member of a high-marketing family have substantially larger inflows after positive returns than otherwise similar funds that 
are operated by a low-marketing family. The results in column B indicate that inflows to low-marketing funds that are operated by a high-marketing family increase with 1.17 percent (0.97 percent plus 0.20 percent) for every one percent increase in prior year return when the return is positive, while inflows to low-marketing funds that are operated by a low-marketing family increase with only 0.97 percent. The difference is statistically significant.

Further, low-marketing funds that are operated by a high-marketing family appear to experience lower outflows after negative performance: while low-marketing funds that are not member of a high-marketing family lose 0.87 percent (0.96 percent minus 0.09 percent) of their assets under management for every one percent decrease in prior year return, funds that are member of a high-marketing family lose only 0.73 percent $(0.96$ percent plus 0.18 percent minus 0.09 percent minus 0.32 percent) of their assets under management.

However, for the subgroups that exclude small and young funds, we do not observe such spillovers. In fact, we observe some sort of cannibalization effects: large and mature funds with low marketing expenses that are member of a high-marketing family appear to have lower inflows after positive returns than otherwise similar funds that are member of a low-marketing family. We do not observe differential outflows after negative returns for these groups of funds. Apparently, membership of a high-marketing family is only beneficial to low-marketing funds that are relatively small and young. This effect could be due to these types of funds having larger search costs (see e.g., Sirri and Tufano (1998)). Nonetheless, our results indicate that high-marketing families provide favorable conditions to incubate new funds. Given the findings of Khorana and Servaes (2005) that families that start more funds have higher market share, one might expect high-marketing families to have a considerable competitive advantage over low-marketing families. 


\section{Interpreting the spillovers: hypothesis development}

One of the most notable observations in the previous section is that high-marketing funds appear to generate spillovers and enhance cash inflows to smaller and younger funds in the family that have low marketing expenses themselves. In the remainder of the paper we take a closer look at this phenomenon.

One interpretation is that the observed spillovers are a by-product of individual fund marketing and distribution whereby the entire family is made more visible to investors, and search costs for small and young funds are lowered. However, a critical assumption underlying this interpretation is that funds' allocated marketing and distribution expenses are directly proportional to the funds' exposure in the media and broker-dealer channels. An alternative explanation for the observed spillovers is that funds with low marketing expenses are directly subsidized by family members with high marketing expenses. A family could pay for advertising and distribution activities of a particular fund through expenses allocated to other funds. There is some anecdotical evidence that lends support to this interpretation. For example, a large number of the funds that are advertised do not charge front-end load fees or $12 \mathrm{~b} 1$ fees themselves. Further, Gallaher et al. (2006) refer to conversations they had with mutual fund family executives, in which the executives indicated that the intent of mutual fund marketing is often not a particular fund, but the fund family itself. Investors who call in on an advertisement of a certain fund may be counseled to invest in other funds of the family. Besides this anecdotical evidence, several academic studies also indicate that families play favorites with their funds. For example, Guedj and Papastaikoudi (2005) and Gaspar et al. (2006) report that families strategically transfer performance across member funds to favor those more likely to increase overall family profits. Cici et al. (2006) even find that institutional managers who engage in sideby-side management of mutual funds and hedge funds, improve the performance of hedge funds at the expense of mutual fund investors. These findings give rise to the notion that the observed spillovers might be related to cross-fund subsidizations. 
We develop and perform a set of tests to evaluate the two alternative hypotheses, i.e., spillovers as a by-product of individual fund marketing and distribution versus spillovers resulting from favoritism. A direct approach to test the subsidization hypothesis would be to investigate whether there are any discrepancies between funds' allocated marketing and distribution expenses and their actual expenditures on marketing and distribution activities. However, while data on funds' allocated marketing and distribution expenses are readily available because of legal requirements, data on funds' actual marketing and distribution expenditures are only very limitedly available. ${ }^{4}$ Because of these data limitations, we employ an indirect approach to investigate whether the observed spillovers are related to intrafamily subsidizations. With this approach, we sort funds into two mutually exclusive groups, where the funds in the first group are member of a family that has strong incentives to engage in subsidization, and the funds in the second group are not. We then test whether there are differences in the observed spillovers between both groups.

The more families finance their marketing and distribution activities by front-end load fees, the stronger their incentives are to pay for advertising and distribution activities of a particular fund through expenses allocated to other funds. Families that finance their marketing and distribution activities by $12 \mathrm{~b} 1$ fees are restricted to engage in significant subsidization because $12 \mathrm{~b} 1$ fees are explicitly earmarked to cover marketing related costs of the funds that charge the fees. Amounts spent under $12 \mathrm{~b} 1$ plans and the reasons for these expenses must be approved by a vote of the funds' directors. Shareholders must also approve increases in a fund's $12 \mathrm{~b} 1$ fee. Because the regulations for charging, spending, and reporting front-end load fees are less strict, fund management companies have fewer restrictions in appropriating them. For example, while funds that are closed to new investors are not allowed to charge $12 \mathrm{~b} 1$ fees, funds that neither advertise, nor use brokers are allowed to consistently charge load fees. ${ }^{5}$

On the other hand, if the spillovers are a by-product of individual fund marketing and distribution, we expect them to be more prevalent in families that finance their marketing and distribution activities by $12 \mathrm{~b} 1$ fees: several authors document that marketing is more effective when financed by $12 \mathrm{~b} 1$ fees because these fees are less salient to investors 
than front-end load fees (see e.g., Barber et al. (2005)). Further, as mentioned earlier, 12b1 families cater a more myopic investor clientele (i.e., investors with shorter investment horizons that are more sensitive to past performance, see Nanda et al. (2006)) which is expected to respond more strongly to marketing and distribution activities. Consequently, if the subsidization hypothesis is true, the spillovers are more prevalent in families with high front-end load fees than in families with high $12 \mathrm{~b} 1$ fees. Otherwise, if the spillovers are a by-product of individual fund marketing and distribution, the spillovers are more prevalent in families with high $12 \mathrm{~b} 1$ fees than in families with high front-end load fees. Hence, we formulate the first testable implication of the subsidization hypothesis:

Hypothesis 1: Spillovers are more prevalent in families with high front-end load fees than in families with high $12 \mathrm{~b} 1$ fees.

Further, since families have fewer restrictions to divert a fund's front-end load fees to subsidize other funds' marketing and distribution activities than $12 \mathrm{~b} 1$ fees, we expect any subsidies to be largely financed by front-end load fees. Therefore, if the subsidization hypothesis is true, front-end load fees are not fully spent on marketing and distribution activities of the load funds themselves. Thus, our second hypothesis is:

Hypothesis 2: Funds with high front-end load fees have a weaker flow-performance relation than funds with high $12 \mathrm{~b} 1$ fees.

Finally, if the subsidization hypothesis is true, there should be a motive for families to subsidize the marketing and distribution of a particular fund through expenses allocated to other funds. Given the observation that a family's overall profits are a direct function of their assets under management, and investors' tendency to disproportionably put their money into particular funds (i.e., young funds, funds with stellar performance, or funds that follow the current "hot" style (Chevalier and Ellison, 1997; Cooper et al., 2005)), families that strategically increase the marketing exposure of some funds at the expense of 
others are expected to have a stronger flow-performance relation than families that do not pursue such a subsidization strategy. Therefore, our third hypothesis reads:

Hypothesis 3: Families with high front-end load fees have a stronger flow-performance relation than families with high $12 \mathrm{~b} 1$ fees.

We test these hypotheses using the empirical framework described in the following section.

\section{Interpreting the spillovers: empirical framework and results}

\section{A Differential flows to low-marketing funds that are member of a high-load and a high-12b1 family}

Our first hypothesis states that if the observed spillovers are because of intrafamily subsidizations, they are more prevalent in families with high front-end load fees than in families with high $12 \mathrm{~b} 1$ fees. To test this hypothesis, we split our sample of low-marketing funds that are member of a high-marketing family into two mutually exclusive groups: lowmarketing funds that are member of a high-load family, and low-marketing funds that are member of a high-12b1 family. High-load families are defined as high-marketing families with front-end load fees greater than the median, and high-12b1 families are defined as high-marketing families with front-end load fees less than or equal to the median. We then test whether there are differences in spillovers between both groups.

First, we investigate spillovers in high-load families, and estimate the following regression model for low-marketing funds that are member of either a high-load or a lowmarketing family:

$$
\begin{array}{r}
F_{i, t+1}=\left(b_{0}+b_{1} \cdot H I G H L O A D_{-} F_{i, t}+b_{2} \cdot I_{i, t}+b_{3} \cdot H I G H L O A D \_F_{i, t} \cdot I_{i, t}\right) \cdot C T R_{i, t}+ \\
a_{0, t}+a_{1, t} \cdot H I G H L O A D \_F_{i, t}+\epsilon_{i, t},
\end{array}
$$


where $H I G H L O A D_{-} F_{i, t}$ is a dummy variable that equals one if fund $i$ is member of a highload family over year $t$, and zero otherwise. The coefficient estimates for HIGHLOAD_F $F_{i, t}$. $C T R_{i, t}$ and HIGHLOAD_F $F_{i, t} \cdot I_{i, t} \cdot C T R_{i, t}$ capture the differential flows to low-marketing funds that are member of a high-load family compared to low-marketing funds that are member of a low-marketing family. We also employ a model specification that extends regression models Eq. (9) with the natural logarithms of the funds' lagged total net assets under management and age. The results are in columns $\mathrm{A}$ and $\mathrm{B}$ of Table 4. The significant positive coefficient estimates for $H I G H L O A D_{-} F_{i, t} \cdot C T R_{i, t}$ indicate the presence of substantial spillovers in high-load families. The results in column B indicate that inflows to low-marketing funds that are member of a high-load family increase with 1.43 percent (0.97 percent plus 0.46 percent) for every one percent increase in prior year return when the return is positive, whereas inflows to low-marketing funds that are member of a low-marketing family increase with only 0.97 percent. Further, the significant negative coefficient estimates for $H I G H L O A D_{-} F_{i, t} \cdot I_{i, t} \cdot C T R_{i, t}$ indicate that low-marketing funds in high-load families experience lower outflows after negative performance than low-marketing funds that are member of a low-marketing family.

Next, we investigate spillovers in high-12b1 families, and estimate the following regression model for low-marketing funds that are member of either a high-12b1 or a lowmarketing family:

$$
\begin{array}{r}
F_{i, t+1}=\left(b_{0}+b_{1} \cdot H I G H 12 B 1_{-} F_{i, t}+b_{2} \cdot I_{i, t}+b_{3} \cdot H I G H 12 B 1_{-} F_{i, t} \cdot I_{i, t}\right) \cdot C T R_{i, t}+ \\
a_{0, t}+a_{1, t} \cdot H I G H 12 B 1_{-} F_{i, t}+\epsilon_{i, t},
\end{array}
$$

where $H I G H 12 B 1_{-} F_{i, t}$ is a dummy variable that equals one if fund $i$ is member of a high$12 \mathrm{~b} 1$ family over year $t$, and zero otherwise. We additionally employ a model specification that augments model Eq. (10) with the natural logarithms of the funds' lagged total net assets under management and age. The results of these regressions are in columns $\mathrm{C}$ and D. Surprisingly, we observe no spillovers whatsoever in high-12b1 families. In fact, the significant negative coefficient estimates for $H I G H 12 B 1_{-} F_{i, t} \cdot C T R_{i, t}$ and the significant positive coefficients estimates for $H I G H 12 B 1_{-} F_{i, t} \cdot I_{i, t} \cdot C T R_{i, t}$ indicate cannibalization of low-marketing funds in high-12b1 families. 
Finally, to test whether the observed differences in spillovers between high-load and high-12b1 families are statistically significant, we estimate regression Eq. (9) for lowmarketing funds that are member of either a high-load or a high-12b1 family. The results are presented in column E. The significant positive coefficient estimate for HIGHLOAD_F $F_{i, t}$. $C T R_{i, t}$ and the negative estimate for $H I G H L O A D_{-} F_{i, t} \cdot I_{i, t} \cdot C T R_{i, t}$ indicate that the spillovers are more prevalent in high-load families, and lend support for the subsidization hypothesis. We also run a model specification that extends regression Eq. (9) with the natural logarithms of the funds' lagged total net assets under management and age. The results of this regression in column $\mathrm{F}$ confirm our previous findings.

We also perform subgroup analyses, and estimate the regressions for (i) low-marketing funds with at least $\$ 15$ million of total net assets under management; (ii) low-marketing funds with at least $\$ 100$ million of total net assets under management; (iii) low-marketing funds that are at least 3 years old; and (iv) low-marketing funds that are at least 5 years old. The regression results are in Table 5 and 6 . The spillovers in high-load families are observed for all subgroups except for low-marketing funds that are at least 5 years old. Further, the cannibalization of low-marketing funds that are member of a high-12b1 family can be observed across all subgroups of funds.

Overall, the results in this subsection are consistently in favor of Hypothesis 1, and lend support to the notion that the observed spillovers are related to intrafamily subsidizations and favoritism.

\section{B Differential flows to high-load and high-12b1 funds}

We now turn to the examination of our second hypothesis. Under the subsidization hypothesis, we expect that funds with high front-end load fees have a weaker flow-performance relation than funds with high $12 \mathrm{~b} 1$ fees. To test this hypothesis, we split our sample of highmarketing funds into two mutually exclusive groups: high-load funds (i.e., high-marketing funds that have front-end load fees greater than the median), and high-12b1 funds (i.e., high-marketing funds that have front-end load fees less than or equal to the median). We then investigate whether there are differences in the flow-performance relation between 
both groups.

To this end, we estimate the following regression for high-load funds and low-marketing funds:

$$
\begin{array}{r}
F_{i, t+1}=\left(b_{0}+b_{1} \cdot H I G H L O A D_{i, t}+b_{2} \cdot I_{i, t}+b_{3} \cdot H I G H L O A D_{i, t} \cdot I_{i, t}\right) \cdot C T R_{i, t}+ \\
a_{0, t}+a_{1, t} \cdot H I G H L O A D_{i, t}+\epsilon_{i, t},
\end{array}
$$

and the following regression for high-12b1 funds and low-marketing funds:

$$
\begin{array}{r}
F_{i, t+1}=\left(b_{0}+b_{1} \cdot H I G H 12 B 1_{i, t}+b_{2} \cdot I_{i, t}+b_{3} \cdot H I G H 12 B 1_{i, t} \cdot I_{i, t}\right) \cdot C T R_{i, t}+ \\
a_{0, t}+a_{1, t} \cdot H I G H 12 B 1_{i, t}+\epsilon_{i, t},
\end{array}
$$

where $H I G H L O A D_{i, t}$ is a dummy variable that indicates if fund $i$ is a high-load fund over year $t$, and $H I G H 12 B 1_{i, t}$ is a dummy variable that indicates if fund $i$ is a high-12b1 fund over year $t$. We also run regressions that augment regression models Eq. (11) and Eq. (12) with the natural logarithms of the funds' lagged total net assets under management and age. The results of these regressions are in columns A to D in Table 7.

The significantly positive coefficient estimates for $H I G H L O A D_{i, t} \cdot C T R_{i, t}$ and $H I G H 12 B 1_{i, t}$. $C T R_{i, t}$ indicate that both high-load and high-12b1 funds have differential inflows after positive returns versus low-marketing funds. However, the differential inflows to high12b1 funds are larger. For example, when we consider the results in column B and D, we observe that inflows to high-load funds increase with 1.76 percent (1.05 percent plus 0.71 percent) for every one percent increase in return when returns are positive, while the inflows to high-12b1 funds increase with 2.21 percent (1.05 percent plus 1.17 percent). Further, the significant negative coefficient estimates for $H I G H L O A D_{i, t} \cdot I_{i, t} \cdot C T R_{i, t}$ and $H I G H 12 B 1_{i, t} \cdot I_{i, t} \cdot C T R_{i, t}$ indicate that both high-load and high-12b1 funds have differential outflows after negative returns.

To test whether the observed differences in the flow-performance relation between highload and high-12b1 funds are statistically significant, we estimate regression Eq. (11) for high-load and high-12b1 funds. In these regressions, the coefficient estimates for $H I G H L O A D_{i, t} \cdot C T R_{i, t}$ and HIGHLOAD $D_{i, t} \cdot I_{i, t} \cdot C T R_{i, t}$ capture the differential flows to high-load funds versus high-12b1 funds. The results are in columns E and F, and clearly in- 
dicate that the flow-performance relation for high-12b1 funds is stronger than for high-load funds. This finding lends further support to the subsidization hypothesis.

\section{Differential flows to high-marketing families}

Finally, we move on to our third hypothesis which states that families with high front-end load fees have a stronger flow-performance relation than families with high $12 \mathrm{~b} 1$ fees. We use a similar approach as in the previous subsections to test this hypothesis, and split our sample of high-marketing families into two mutually exclusive groups of high-load families and high-12b1 families, and test whether there are any differences in the flow-performance relation between both groups.

However, before we perform this test, we first investigate whether high-marketing families have a differential flow-performance relation versus low-marketing families. To this end, we estimate the following regression model:

$$
\begin{array}{r}
F_{f, t+1}=\left(b_{0}+b_{1} \cdot T O P 50 T X_{f, t}+b_{2} \cdot I_{f, t}+b_{3} \cdot T O P 50 T X_{f, t} \cdot I_{f, t}\right) \cdot C T R_{f, t}+ \\
a_{0, t}+a_{1, t} \cdot T O P 50 T X_{f, t}+\epsilon_{f, t},
\end{array}
$$

where $T O P 50 T X_{f, t}$ is a dummy variable that equals one if the family's marketing and distribution expenses are greater than the median over year $t$, and zero otherwise. Further, $I_{f, t}$ is an indicator variable that equals one if family $f$ 's return over year $t$ is negative, and zero otherwise. Additionally, we employ a regression specification that extends Eq. (13) with family $f$ 's total net assets under management $\left(\ln \left(T N A_{f, t}\right)\right)$ and average fund age $\left(\ln \left(A G E_{f, t}\right)\right.$. The results of these regressions in columns $\mathrm{A}$ and $\mathrm{B}$ of Table 8 indicate that high-marketing families do not appear to have a stronger flow-performance relation than low-marketing families. In fact, the negative coefficient estimates for TOP50T $X_{f, t}$. $C T R_{f, t}$ indicate that low-marketing families have larger inflows following positive returns, and the positive coefficient estimates for $T O P 50 T X_{f, t} \cdot I_{f, t} \cdot C T R_{f, t}$ indicate that lowmarketing families have lower outflows after negative returns. Given the results of Gallaher et al. (2006) that marketing only works for top-advertising families, we re-estimate the regressions where we replace $T O P 50 T X_{f, t}$ with a dummy variable that equals one if the family's marketing and distribution expenses are greater than the 3rd quartile over year $t$, 
and zero otherwise $\left(T O P 25 T X_{f, t}\right)$. The results of these regressions are in columns $\mathrm{C}$ and D. Now we find clear evidence that families with the highest marketing and distribution expenses have a stronger flow performance relation. For example, when we consider the results in column D, it appears that inflows to low-marketing families (bottom 75 percent) increase with 0.68 percent for every one percent increase in prior year return when the return is positive, while inflows to high-marketing families (top 25 percent) increase with 1.56 percent (0.68 percent plus 0.88 percent).

This bring us to Hypothesis 3. First, we split our sample of high-marketing families (top 25 percent) into two mutually exclusive groups: high-load families (i.e., high-marketing families that have front-end load fees greater than the 3rd quartile), and high-12b1 families (i.e., high-marketing families that have front-end load fees less than or equal to the 3rd quartile.). We then estimate the following regression for high-load families and lowmarketing families:

$$
\begin{array}{r}
F_{f, t+1}=\left(b_{0}+b_{1} \cdot T O P 25 L O A D_{f, t}+b_{2} \cdot I_{f, t}+b_{3} \cdot T O P 25 L O A D_{f, t} \cdot I_{i, t}\right) \cdot C T R_{f, t}+ \\
a_{0, t}+a_{1, t} \cdot T O P 25 L O A D_{f, t}+\epsilon_{f, t}
\end{array}
$$

and the following regression for high-12b1 families and low-marketing families:

$$
\begin{array}{r}
F_{f, t+1}=\left(b_{0}+b_{1} \cdot T O P 2512 B 1_{f, t}+b_{2} \cdot I_{f, t}+b_{3} \cdot T O P 2512 b 1_{f, t} \cdot I_{i, t}\right) \cdot C T R_{f, t}+ \\
a_{0, t}+a_{1, t} \cdot T O P 2512 B 1_{f, t}+\epsilon_{f, t}
\end{array}
$$

where TOP25LOAD $f, t$ is a dummy variable that equals one if family $f$ is a high-load family over year $t$, and zero otherwise, and $T O P 2512 B 1_{f, t}$ is a dummy variable that equals one if family $f$ is a high-12b1 family over year $t$, and zero otherwise. In addition, we employ augmented specifications that include the families' total net assets under management and average fund age. The results are in columns E to H. It appears that only the high-load families have a stronger flow performance relation. To test the statistical significance of the difference in the flow-performance relation between high-load and high-12b1 families, we estimate regression Eq. (14) and the augmented specification for high-load families and high-12b1 families. The results in column I and J indicate that high-load families have larger inflows following positive returns than high-12b1 families, and provide further evidence supporting the subsidization hypothesis. 


\section{Conclusion}

In this paper, we investigate the impact of mutual fund marketing and distribution activities on other funds in the family. We find that high-marketing funds generate spillovers, and enhance cash inflows to low-marketing funds in the same family. Small and young low-marketing funds that are operated by a family with high marketing expenses have substantially larger inflows after positive returns than otherwise similar funds that are operated by a family with low marketing expenses.

One interpretation of these results is that the observed spillovers are a by-product of individual fund marketing whereby the entire family is made more visible to investors, and search costs for small and young funds are lowered. A critical assumption underlying this interpretation is that funds' allocated marketing and distribution expenses are directly proportional to the funds' exposure in the media and broker-dealer channels. An alternative explanation of this observation is that funds with low marketing expenses are directly subsidized by family members with high marketing expenses. A family could pay for advertising and distribution activities of a certain fund through expenses allocated to other funds. We develop and perform a set of tests to evaluate the alternative hypotheses. The body of evidence in this paper supports the subsidization hypothesis, and suggests that at least a part of the spillovers can be attributed to favoritism towards particular funds.

While it is conceivable that fund families engage in cross-subsidization, these results are remarkable. As argued by Khorana and Servaes (2005), given the low entry barriers of the mutual fund industry and the large number of participants, one might expect that conflicts of interest between investors and investment companies are mitigated by competition. However, our finding that families that play favorites with their funds and pay for the marketing of a particular fund through expenses allocated to other funds suggests that conflicts of interest between investors and fund families have actually been exacerbated by competition in the mutual fund industry. 


\section{Notes}

${ }^{1}$ As a measure of funds' marketing and distribution expenses we take the funds' reported $12 \mathrm{~b} 1$ fees plus one-seventh of the funds' front-end load fees.

${ }^{2}$ While most authors report a convex relation between fund flows and past performance (see e.g., Sirri and Tufano (1998) and Chevalier and Ellison (1999)), some recent evidence indicates that the relation has become more linear during the nineties compared to the previous two decades (Sigurdsson, 2004).

${ }^{3}$ With the cross-sectional Fama and MacBeth (1973) regressions, we replace the year dummies with a constant.

${ }^{4}$ While Competitive Media Research (CMR) distributes data on mutual funds' actual advertising expenditures, we are not aware of any information service that provides an extensive database on the entire spectrum of mutual fund marketing and distribution activities, including sales-promotion activities and compensation for broker-dealer sales professionals.

${ }^{5}$ Closed funds are allowed to spread marketing and distribution expenses over several years, and may charge 12b-1 fees to fulfill obligations for past distribution efforts. 


\section{References}

B. M. Barber, T. Odean, and L. Zheng. Out of sight, out of mind: The effects of expenses on mutual fund flows. Journal of Business, 78:2095-2120, 2005.

N. P. B. Bollen. Mutual fund attributes and investor behavior. Journal of Financial and Quantitative Analysis, forthcoming, 2006.

S. J. Brown and W. Goetzmann. Performance persistence. Journal of Finance, 50:679-698, 1995.

S. J. Brown, W. Goetzmann, R. G. Ibbotson, and S. A. Ross. Survivorship bias in performance studies. Review of Financial Studies, 5:553-580, 1992.

J. Chevalier and G. Ellison. Risk taking by mutual funds as a response to incentives. Journal of Political Economy, 105:1167-1200, 1997.

J. Chevalier and G. Ellison. Career concerns for mutual funds managers. Quarterly Journal of Economics, 114:389-432, 1999.

G. Cici, S. Gibson, and R. Moussawia. For better or worse? Mutual funds in side-by-side management relationships with hedge funds. Working paper The Wharton School, 2006.

M. J. Cooper, H. Gulen, and R. P. Rau. Changing names with style: Mutual fund name changes and their effects on fund flows. Journal of Finance, 60:2825-2858, 2005.

D. Del Guercio and P. Tkac. The determinants of the flows of funds of managed portfolios: Mutual funds versus pension funds. Journal of Financial and Quantitative Analysis, 37: 523-557, 2002.

E. F. Fama and J. D. MacBeth. Risk, return, and equilibrium: Empirical tests. Journal of Political Economy, 81:607-636, 1973.

S. Gallaher, R. Kaniel, and L. Starks. Madison avenue meets wall street: Mutual fund families, competition, and advertising. Working paper University of Texas, 2006. 
J. M. Gaspar, M. Massa, and P. Matos. Favoritism in mutual fund families? Evidence on strategic cross-fund subsidization. Journal of Finance, 61:73-104, 2006.

W. N. Goetzmann and R. G. Ibbotson. Games mutual fund companies play: Strategic response to investor beliefs in the mutual fund industry. Working paper Yale School of Management, 1993.

M. J. Gruber. Another puzzle: The growth in actively managed mutual funds. Journal of Finance, 51:783-810, 1996.

I. Guedj and J. Papastaikoudi. Can mutual fund families affect the performance of their funds? Working paper McCombs School of Business, 2005.

J. Huij and M. Verbeek. Cross-sectional learning and short-run persistence in mutual fund performance. Journal of Banking and Finance, forthcoming, 2007.

Z. Ivkovic. Is blood thicker than water: Spillovers in mutual fund families. working paper University of Illinois at Urbana-Champaign, 2001.

P. C. Jain and J. S. Wu. Thruth in mutual fund advertising: Evidence on future performance and fund flow. Journal of Finance, 55:937-958, 2000.

A. Khorana and H. Servaes. Conflicts of interest and competition in the mutual fund industry. Working paper London Business School, 2005.

V. Nanda, J. Wang, and L. Zheng. The ABCs of mutual funds: On the introduction of multiple share classes. Working paper University of Michigan, 2006.

V. Nanda, J. Z. Wang, and L. Zheng. Famility values and the star phenomenon: Strategies of mutual fund families. Review of Financial Studies, 17:667-697, 2004.

L. Pastor and R. F. Stambaugh. Investing in equity mutual funds. Journal of Financial Economics, 63:351-380, 2002a. 
L. Pastor and R. F. Stambaugh. Mutual fund performance and seemingly unrelated assets. Journal of Financial Economics, 63:315-349, 2002b.

K. Sigurdsson. The effect of new money inflows on the flow-performance relationship in the U.S. mutual fund industry. Working paper London Business School, 2004.

E. R. Sirri and P. Tufano. Costly search and mutual fund flows. Journal of Finance, 53: 1589-1622, 1998.

X. Zhao. Why are some mutual funds closed to new investors? Journal of Banking and Finance, 28:1867-1887, 2004.

L. Zheng. Is money smart? a study of mutual fund investors' fund selection ability. Journal of Finance, 54:901-933, 1999. 


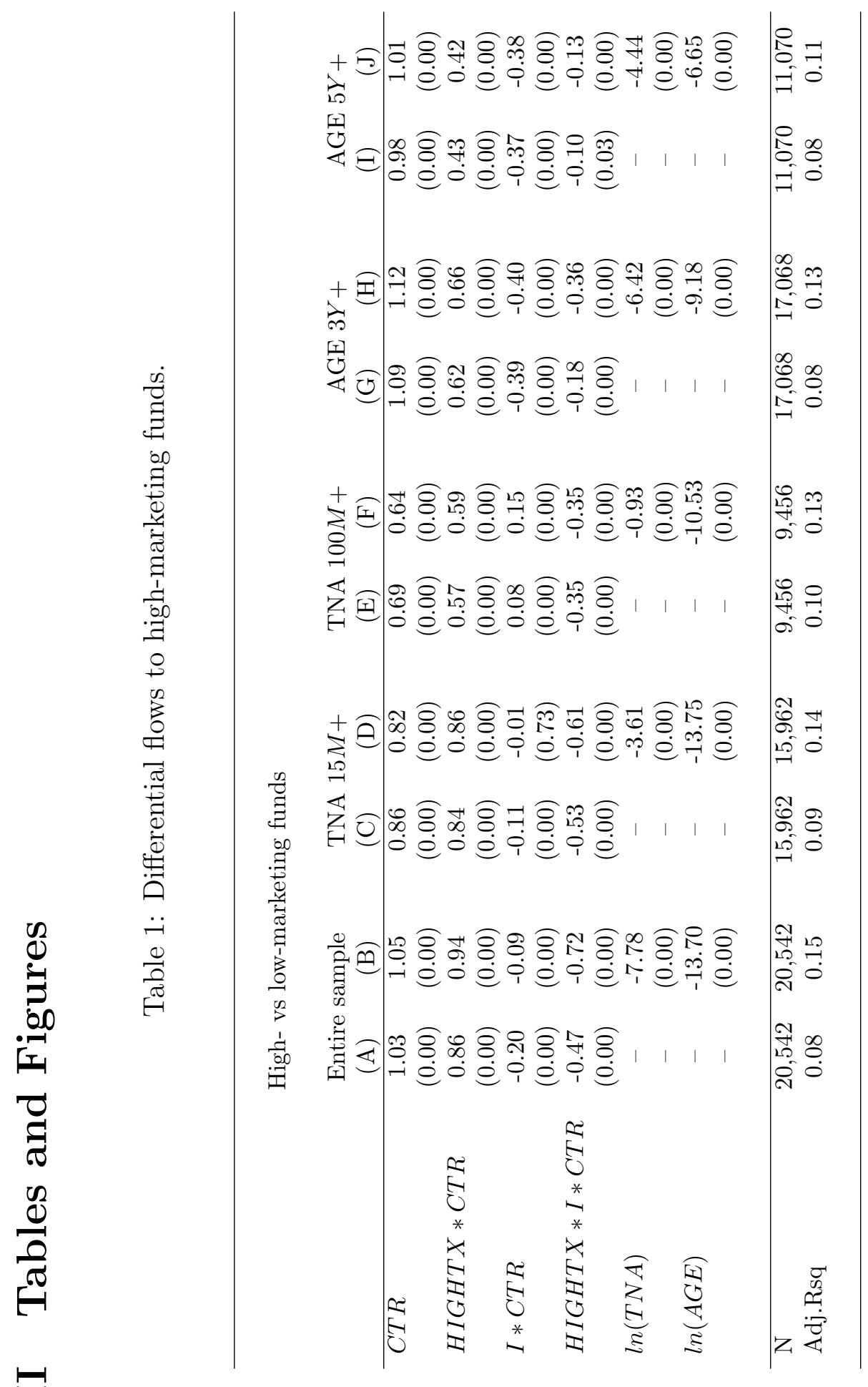




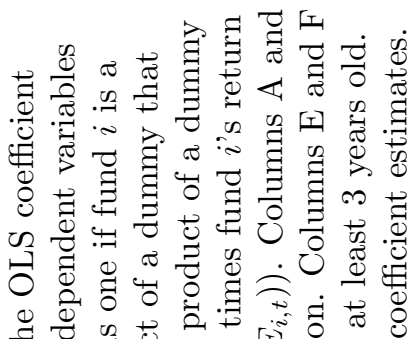

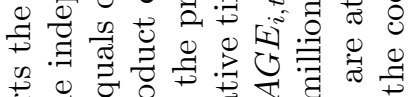

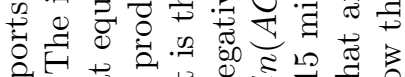

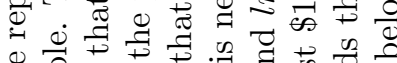

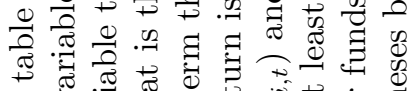

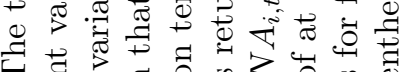

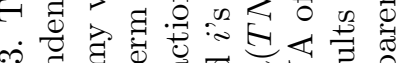

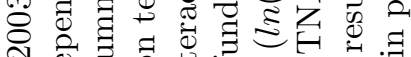

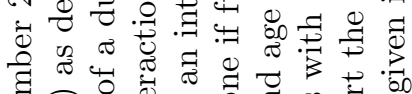

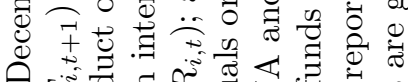

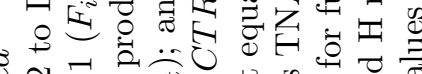

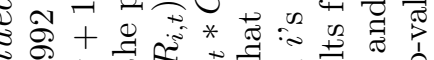

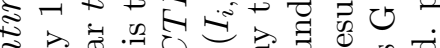

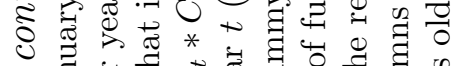

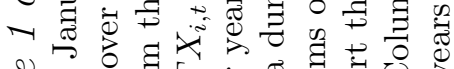

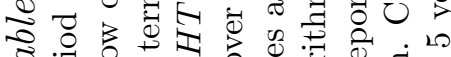
잉 可

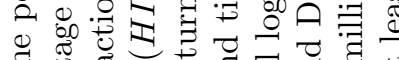

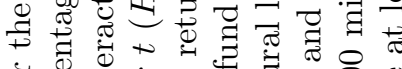

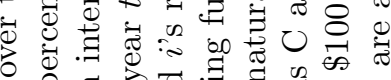

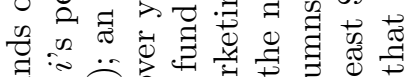
$\exists \nabla 20$ क

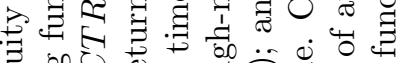

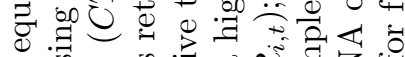

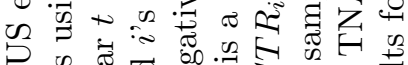

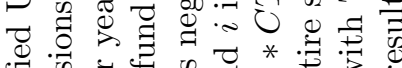

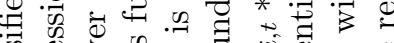
के

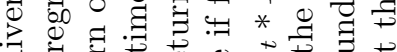

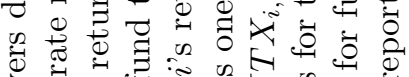
范:

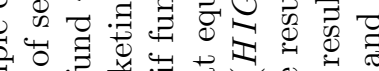

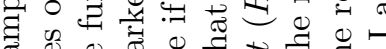

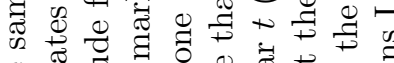

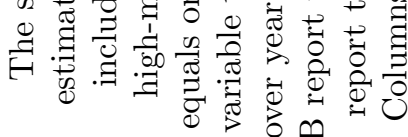




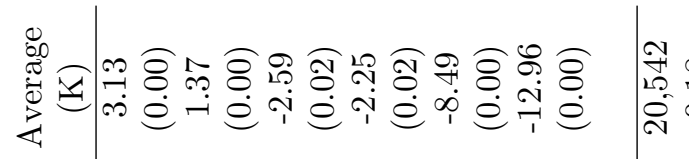

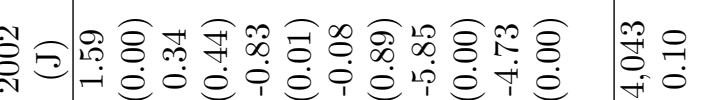

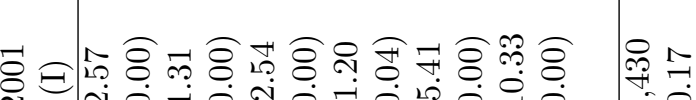

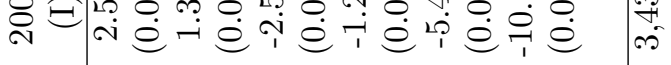

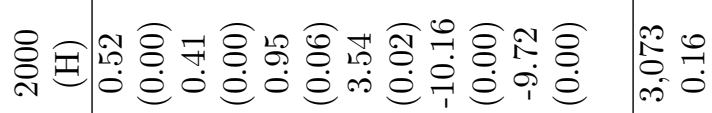

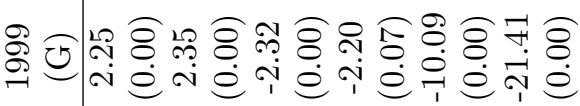

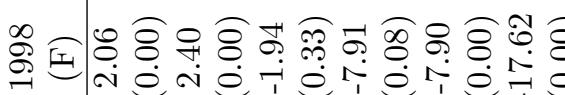

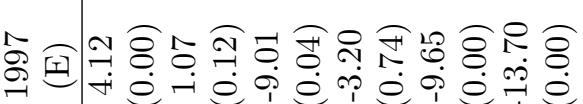

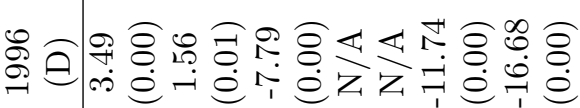

焉

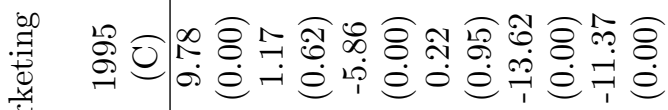

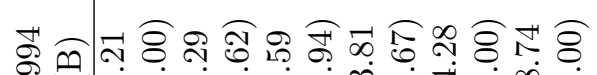

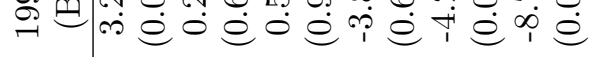

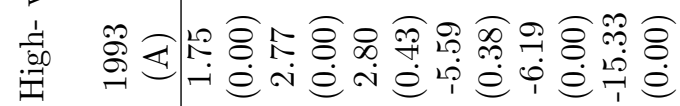

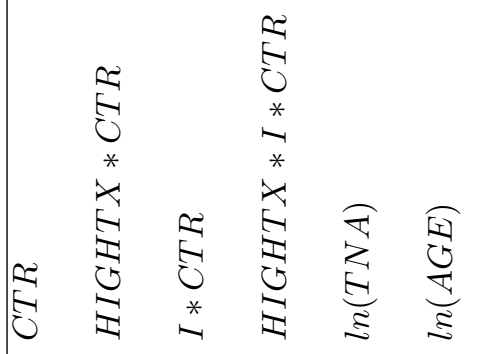

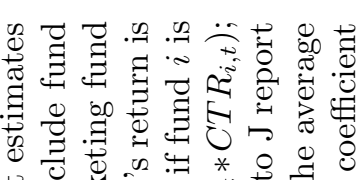

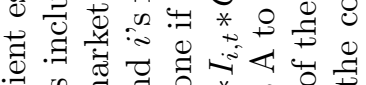
可

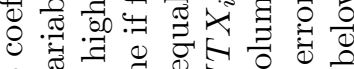

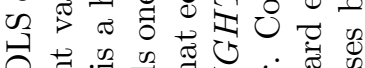

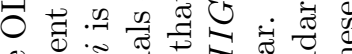

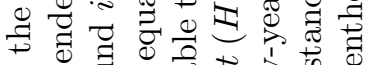

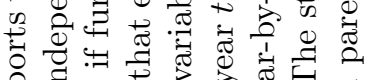
이의

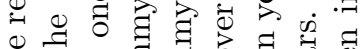
蛋

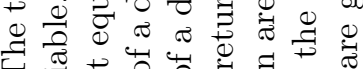

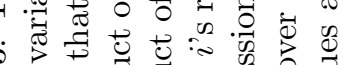

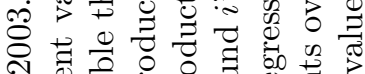

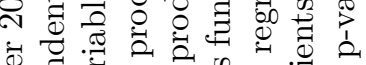
है चี ष คิ พ + a S.

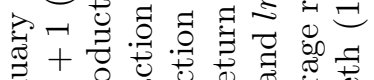

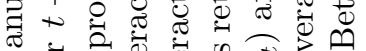

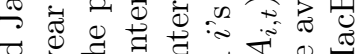

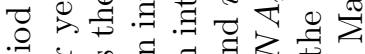

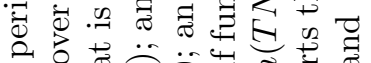

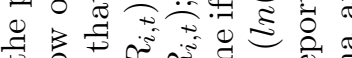
ॠ है

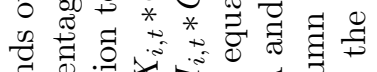

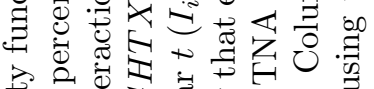

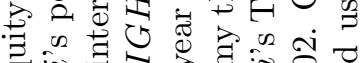
F $: \approx$ :

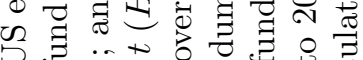

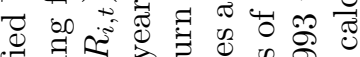

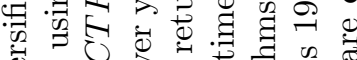

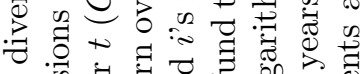
品

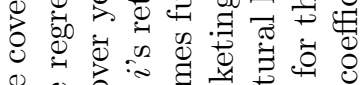

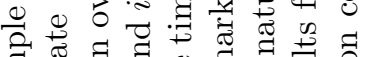

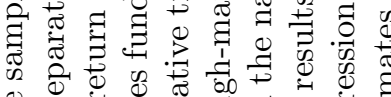

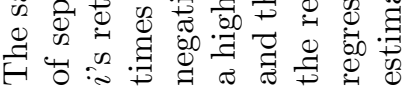




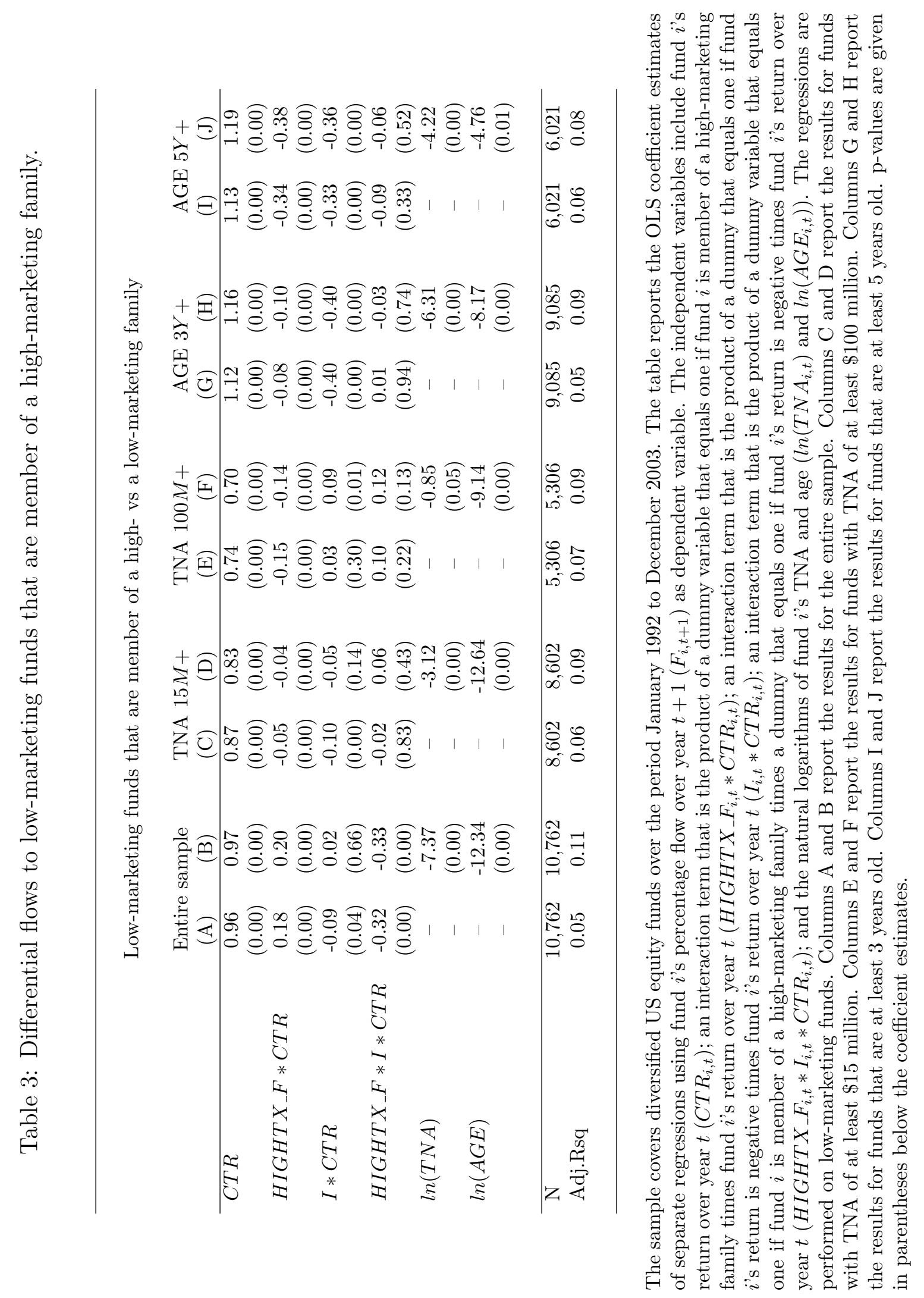


Table 4: Differential flows to low-marketing funds that are member of a high-load and a high-12b1 family.

\begin{tabular}{|c|c|c|c|c|c|c|}
\hline & \multicolumn{2}{|c|}{$\begin{array}{l}\text { Low-marketing funds } \\
\text { that are member of } \\
\text { a high-load vs } \\
\text { a low-marketing } \\
\text { family }\end{array}$} & \multicolumn{2}{|c|}{$\begin{array}{l}\text { Low-marketing funds } \\
\text { that are member of } \\
\text { a high-12b1 vs } \\
\text { a low-marketing } \\
\text { family }\end{array}$} & \multicolumn{2}{|c|}{$\begin{array}{l}\text { Low-marketing funds } \\
\text { that are member of } \\
\text { a high-load vs } \\
\text { a high-12b1 } \\
\text { family }\end{array}$} \\
\hline & $(\mathrm{A})$ & $(\mathrm{B})$ & $(\mathrm{C})$ & (D) & $(\mathrm{E})$ & $(\mathrm{F})$ \\
\hline \multirow[t]{2}{*}{$C T R$} & 0.96 & 0.97 & 0.96 & 0.96 & 0.83 & 0.86 \\
\hline & $(0.00)$ & $(0.00)$ & $(0.00)$ & $(0.00)$ & $(0.00)$ & $(0.00)$ \\
\hline \multirow[t]{2}{*}{$H I G H L O A D \_F * C T R$} & 0.44 & 0.46 & - & - & 0.56 & 0.58 \\
\hline & $(0.00)$ & $(0.00)$ & - & - & $(0.00)$ & $(0.00)$ \\
\hline \multirow[t]{2}{*}{$H I G H 12 B 1_{-} F * C T R$} & - & - & -0.13 & -0.13 & - & - \\
\hline & - & - & $(0.00)$ & $(0.00)$ & - & - \\
\hline \multirow[t]{2}{*}{$I * C T R$} & -0.09 & 0.02 & -0.09 & 0.02 & 0.51 & 0.60 \\
\hline & $(0.03)$ & $(0.66)$ & $(0.05)$ & $(0.67)$ & $(0.11)$ & $(0.04)$ \\
\hline \multirow[t]{2}{*}{$H I G H L O A D \_F * I * C T R$} & -0.75 & -0.76 & - & - & -1.35 & -1.39 \\
\hline & $(0.00)$ & $(0.00)$ & - & - & $(0.00)$ & $(0.00)$ \\
\hline \multirow[t]{2}{*}{$12 B 1_{-} F * I * C T R$} & - & - & 0.59 & 0.65 & - & - \\
\hline & - & - & $(0.11)$ & $(0.06)$ & - & - \\
\hline \multirow[t]{2}{*}{$\ln (T N A)$} & - & -7.20 & - & -6.55 & - & -8.89 \\
\hline & - & $(0.00)$ & - & $(0.00)$ & - & $(0.00)$ \\
\hline \multirow[t]{2}{*}{$\ln (A G E)$} & - & -12.62 & - & -14.51 & - & -7.81 \\
\hline & - & $(0.00)$ & - & $(0.00)$ & - & $(0.03)$ \\
\hline $\mathrm{N}$ & 10,029 & 10,029 & 6,925 & 6,925 & 4,570 & 4,570 \\
\hline Adj.Rsq & 0.05 & 0.11 & 0.05 & 0.10 & 0.06 & 0.12 \\
\hline
\end{tabular}

The sample covers diversified US equity funds over the period January 1992 to December 2003. The table reports the OLS coefficient estimates of separate regressions using fund $i$ 's percentage flow over year $t+1$ $\left(F_{i, t+1}\right)$ as dependent variable. The independent variables include fund $i$ 's return over year $t\left(C T R_{i, t}\right)$; an interaction term that is the product of a dummy variable that equals one if fund $i$ is member of a highload family times fund $i$ 's return over year $t$ (HIGHLOAD_F $\left.F_{i, t} * C T R_{i, t}\right)$; an interaction term that is the product of a dummy variable that equals one if fund $i$ is member of a high-12b1 family times fund $i$ 's return over year $t$ (HIGH12B1_ $\left.F_{i, t} * C T R_{i, t}\right)$; an interaction term that is the product of a dummy that equals one if fund $i$ 's return is negative times fund $i$ 's return over year $t\left(I_{i, t} * C T R_{i, t}\right)$; an interaction term that is the product of a dummy variable that equals one if fund $i$ is member of a high-load family times a dummy that equals one if fund $i$ 's return is negative times fund $i$ 's return over year $t$ (HIGHLOAD_F $\left.F_{i, t} * I_{i, t} * C T R_{i, t}\right)$; an interaction term that is the product of a dummy variable that equals one if fund $i$ is member of a high-12b1 family times a dummy that equals one if fund $i$ 's return is negative times fund $i$ 's return over year $t$ (HIGH12b1_ $\left.F_{i, t} * I_{i, t} * C T R_{i, t}\right)$; and the natural logarithms of fund $i$ 's TNA and age $\left(\ln \left(T N A_{i, t}\right)\right.$ and $\left.\ln \left(A G E_{i, t}\right)\right)$. The regressions in columns $\mathrm{A}$ and $\mathrm{B}$ are performed on low-marketing funds that are member of either a high-load or a low-marketing family. The regressions in columns $\mathrm{C}$ and $\mathrm{D}$ are performed on low-marketing funds that are member of either a high-12b1 or a low-marketing family. The regressions in columns $\mathrm{E}$ and $\mathrm{F}$ are performed on low-marketing funds that are member of a high-marketing family. p-values are given in parentheses below the coefficient estimates. 

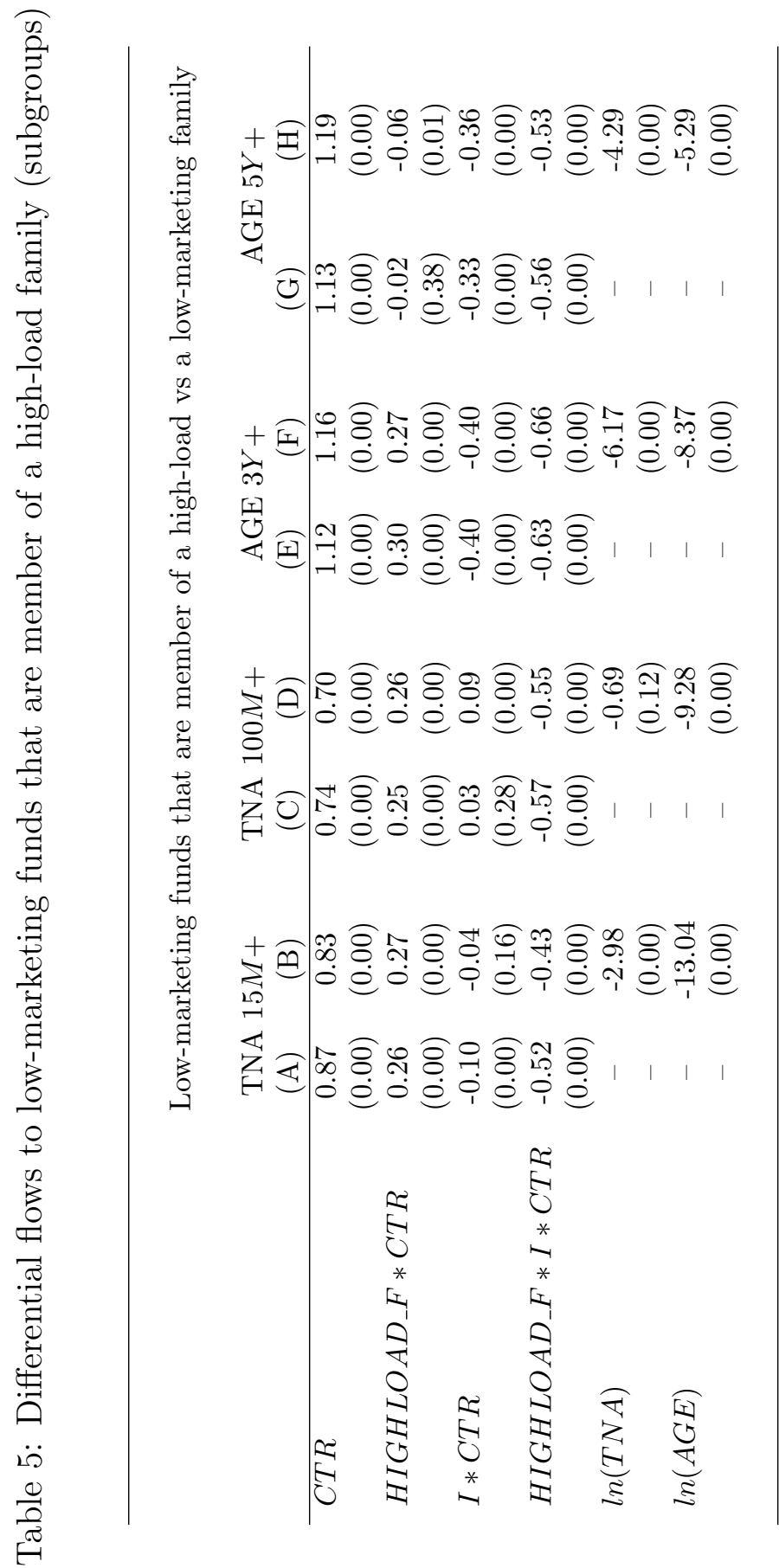

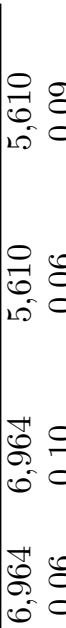

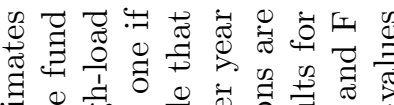

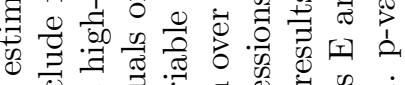

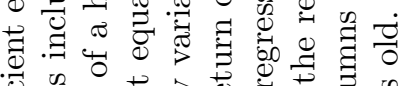

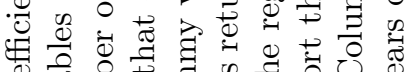

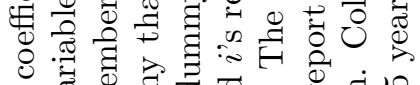

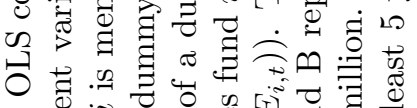

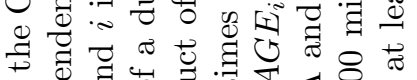
औ

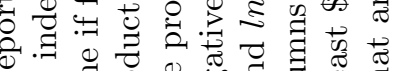
ब.च

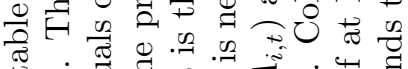

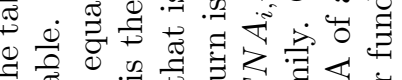

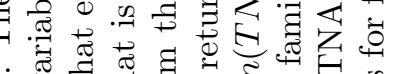

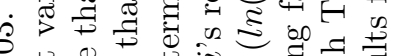

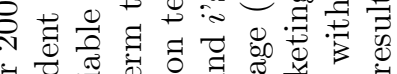

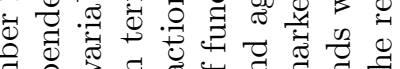
萢

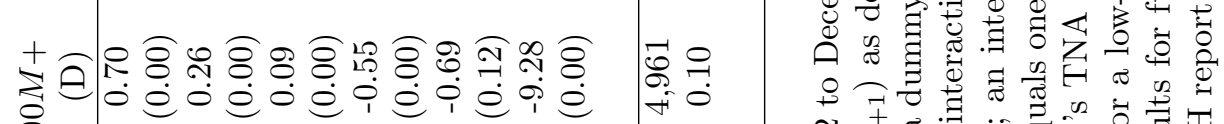

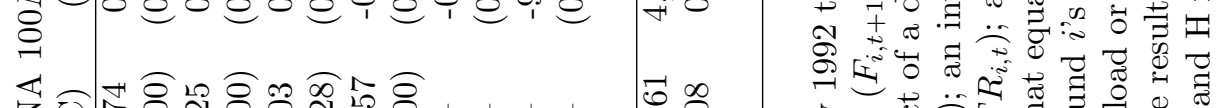

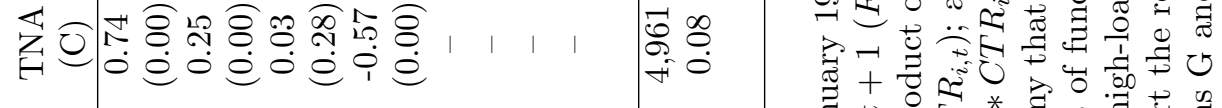

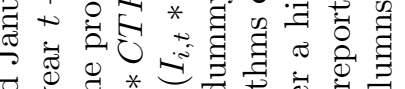

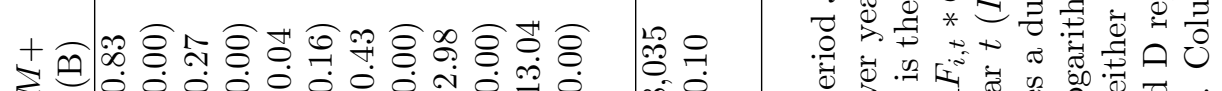

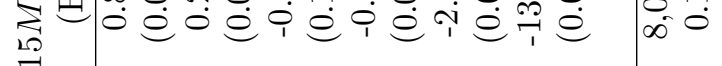
㕕药 $\stackrel{2}{20}$

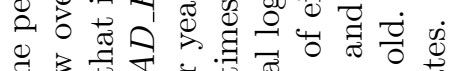

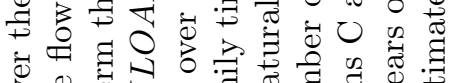
ठั

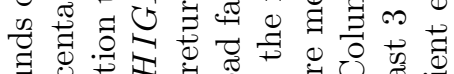

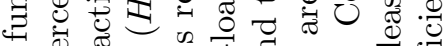

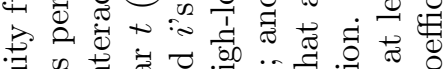

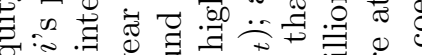

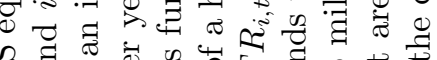

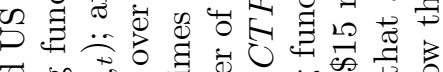
o

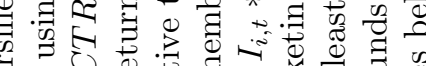

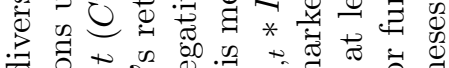

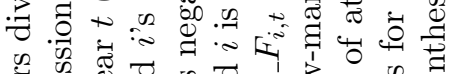

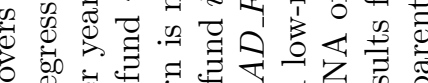

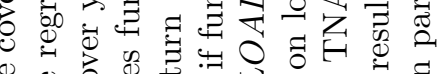

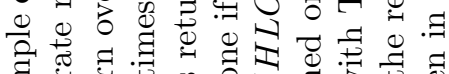

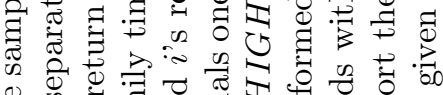

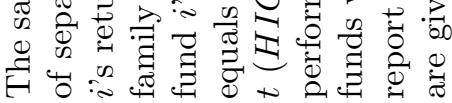



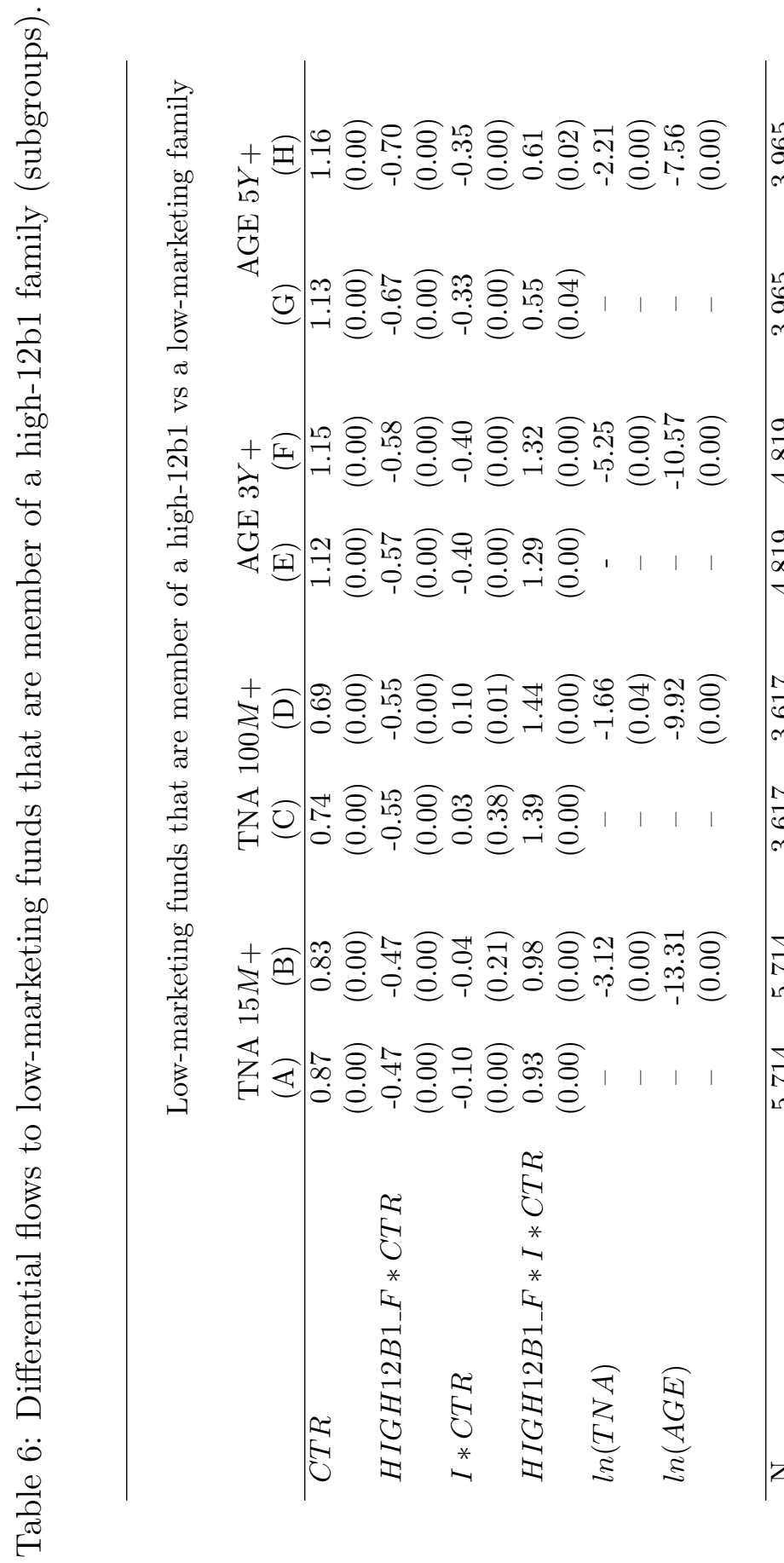

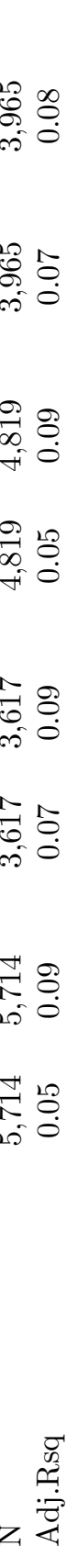

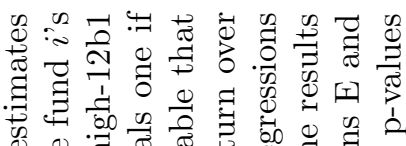

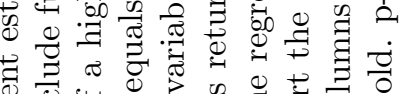

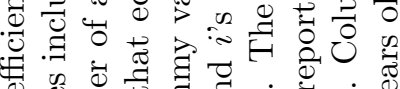

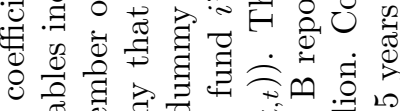

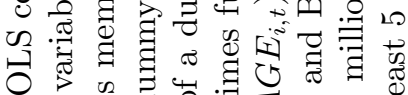

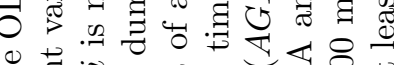

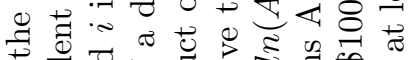

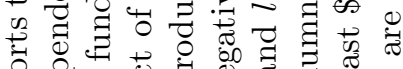

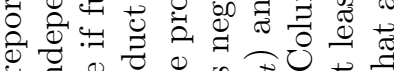
讨

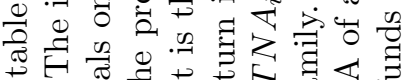

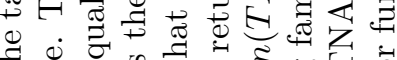

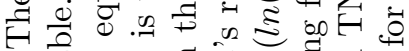

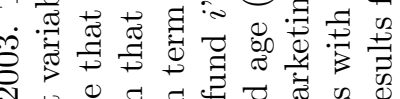

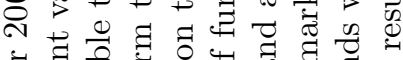

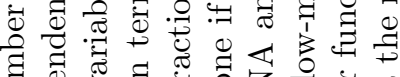
वृ

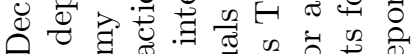

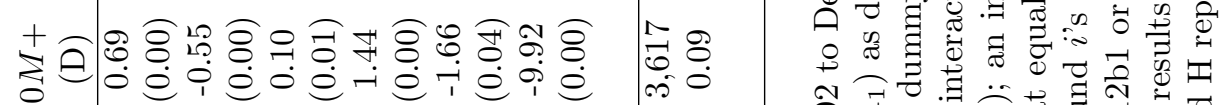

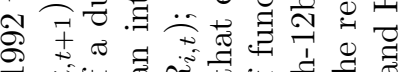

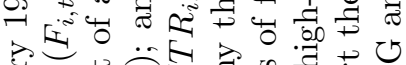

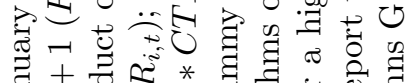

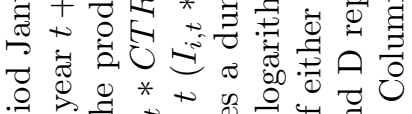

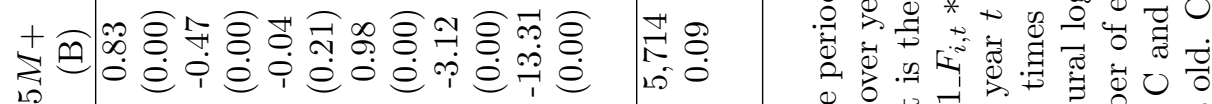

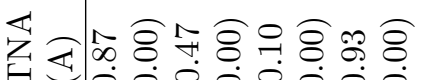

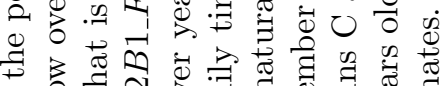
के

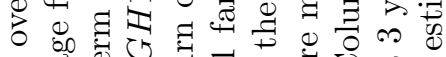

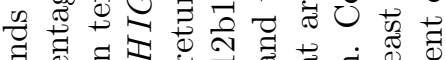
吉

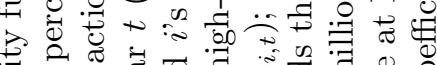

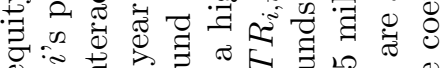

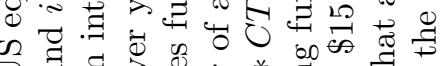

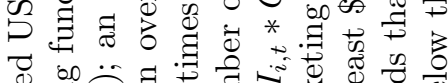

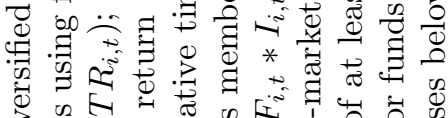

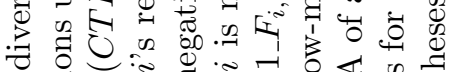

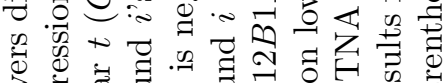
ठ⿹

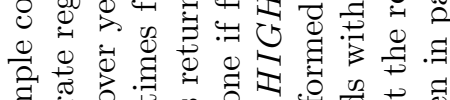

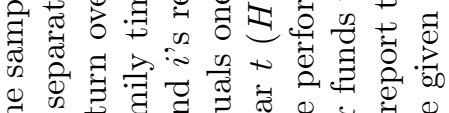

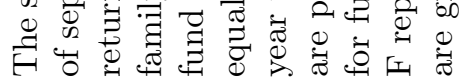


Table 7: Flows to high-load vs high-12b1 funds.

\begin{tabular}{|c|c|c|c|c|c|c|}
\hline & \multicolumn{2}{|c|}{$\begin{array}{l}\text { High-load vs } \\
\text { low-marketing funds }\end{array}$} & \multicolumn{2}{|c|}{$\begin{array}{l}\text { High-12b1 vs } \\
\text { low-marketing funds }\end{array}$} & \multicolumn{2}{|c|}{$\begin{array}{l}\text { High-load vs } \\
\text { high-12b1-funds }\end{array}$} \\
\hline & $(\mathrm{A})$ & (B) & (C) & (D) & $(\mathrm{E})$ & $(\mathrm{F})$ \\
\hline \multirow[t]{2}{*}{$C T R$} & 1.03 & 1.05 & 1.03 & 1.05 & 2.08 & 2.22 \\
\hline & $(0.00)$ & $(0.00)$ & $(0.00)$ & $(0.00)$ & $(0.00)$ & $(0.00)$ \\
\hline \multirow[t]{2}{*}{$H I G H L O A D * C T R$} & 0.69 & 0.71 & - & - & -0.36 & -0.45 \\
\hline & $(0.00)$ & $(0.00)$ & - & - & $(0.00)$ & $(0.00)$ \\
\hline \multirow[t]{2}{*}{$H I G H 12 B 1 * C T R$} & - & - & 1.05 & 1.17 & - & - \\
\hline & - & - & $(0.00)$ & $(0.00)$ & - & - \\
\hline \multirow[t]{2}{*}{$I * C T R$} & -0.20 & -0.10 & -0.20 & -0.08 & -0.51 & -0.78 \\
\hline & $(0.00)$ & $(0.00)$ & $(0.00)$ & $(0.00)$ & $(0.00)$ & $(0.00)$ \\
\hline \multirow[t]{2}{*}{$H I G H L O A D * I * C T R$} & -0.66 & -0.79 & - & - & -0.35 & -0.11 \\
\hline & $(0.00)$ & $(0.00)$ & - & - & $(0.00)$ & $(0.28)$ \\
\hline \multirow[t]{2}{*}{$H I G H 12 B 1 * I * C T R$} & - & - & -0.31 & -0.69 & - & - \\
\hline & - & - & $(0.00)$ & $(0.00)$ & - & - \\
\hline \multirow[t]{2}{*}{$\ln (T N A)$} & - & -7.33 & - & -7.89 & - & -8.44 \\
\hline & - & $(0.00)$ & - & $(0.00)$ & - & $(0.00)$ \\
\hline \multirow[t]{2}{*}{$\ln (A G E)$} & - & -11.64 & - & -14.69 & - & -13.60 \\
\hline & - & $(0.00)$ & - & $(0.00)$ & - & $(0.00)$ \\
\hline $\mathrm{N}$ & 15,859 & 15,859 & 15,445 & 15,445 & 9,780 & 9,780 \\
\hline Adj.Rsq & 0.05 & 0.12 & 0.08 & 0.15 & 0.12 & 0.20 \\
\hline
\end{tabular}

The sample covers diversified US equity funds over the period January 1992 to December 2003. The table reports the OLS coefficient estimates of separate regressions using fund $i$ 's percentage flow over year $t+1\left(F_{i, t+1}\right)$ as dependent variable. The independent variables include fund $i$ 's return over year $t\left(C T R_{i, t}\right)$; an interaction term that is the product of a dummy variable that equals one if fund $i$ is a high-load fund times fund $i$ 's return over year $t\left(H I G H L O A D_{i, t} * C T R_{i, t}\right)$; an interaction term that is the product of a dummy variable that equals one if fund $i$ is a high-12b1 fund times fund $i$ 's return over year $t$ ( $\left.H I G H 12 B 1_{i, t} * C T R_{i, t}\right)$; an interaction term that is the product of a dummy that equals one if fund $i$ 's return is negative times fund $i$ 's return over year $t\left(I_{i, t} * C T R_{i, t}\right)$; an interaction term that is the product of a dummy variable that equals one if fund $i$ is a high-load fund times a dummy that equals one if fund $i$ 's return is negative times fund $i$ 's return over year $t\left(H I G H L O A D_{i, t} * I_{i, t} * C T R_{i, t}\right)$; an interaction term that is the product of a dummy variable that equals one if fund $i$ is a high-12b1 fund times a dummy that equals one if fund $i$ 's return is negative times fund $i$ 's return over year $t\left(H I G H 12 B 1_{i, t} * I_{i, t} * C T R_{i, t}\right)$; and the natural logarithms of fund $i$ 's TNA and age $\left(\ln \left(T N A_{i, t}\right)\right.$ and $\left.\ln \left(A G E_{i, t}\right)\right)$. The regressions in column $\mathrm{A}$ are performed on high-load and low-marketing funds. The regressions in column $\mathrm{B}$ are performed on high-12b1 and low-marketing funds. The regressions in column $\mathrm{C}$ are performed on high-marketing funds. p-values are given in parentheses below the coefficient estimates. 


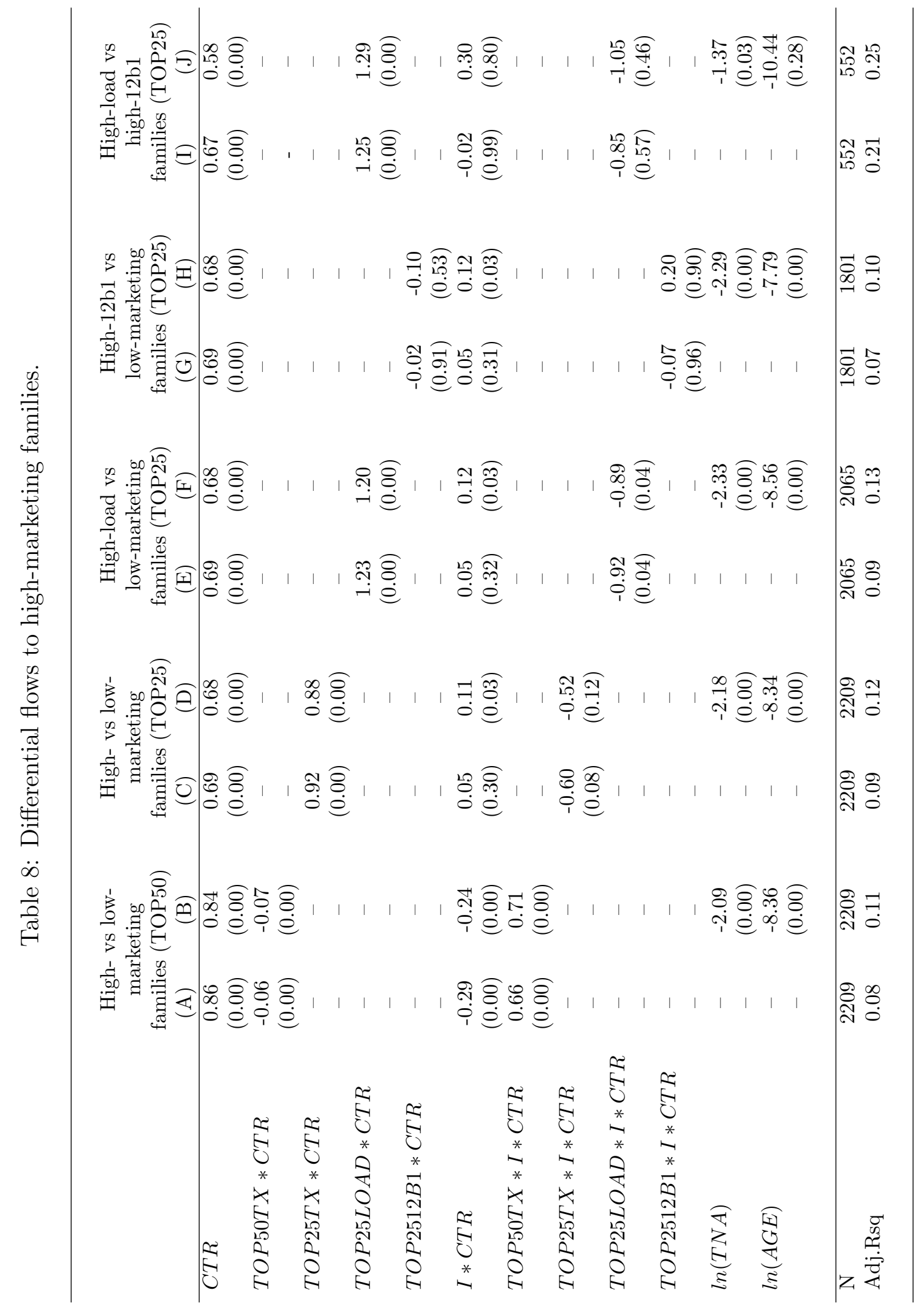




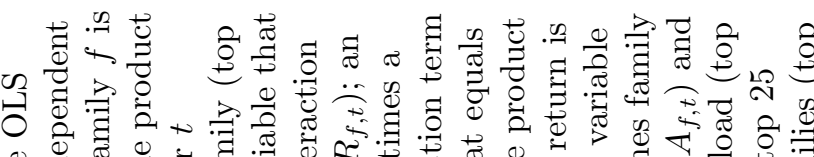

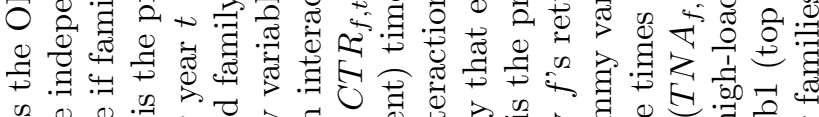

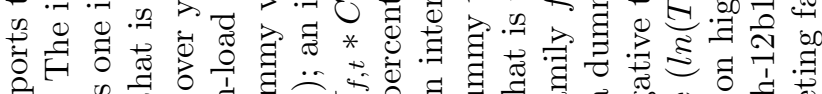

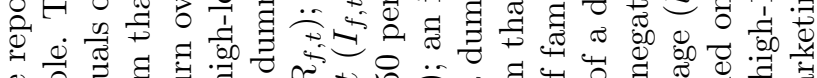

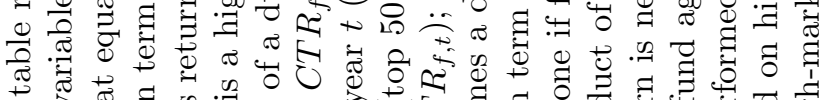

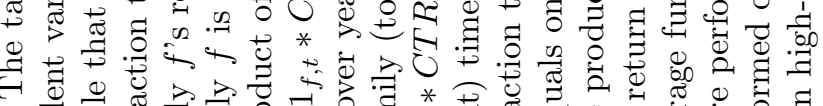

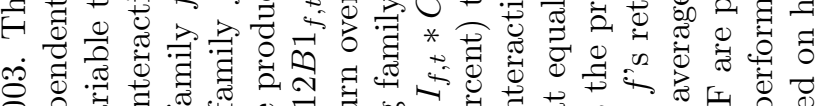

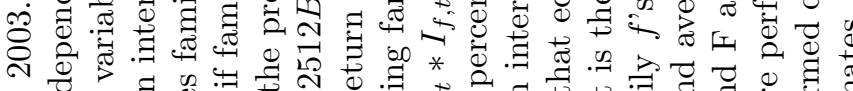

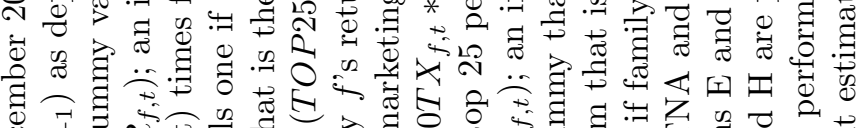

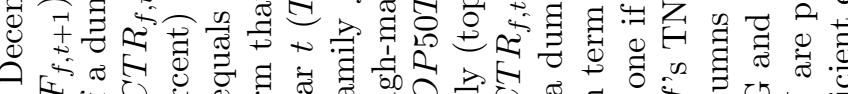

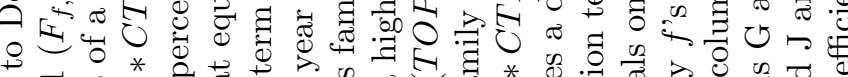

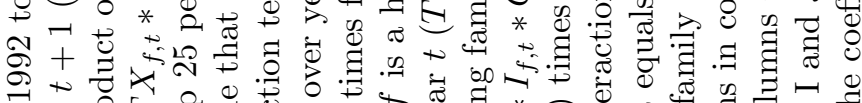

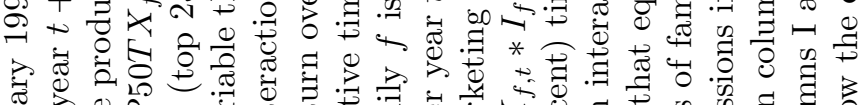
Ð

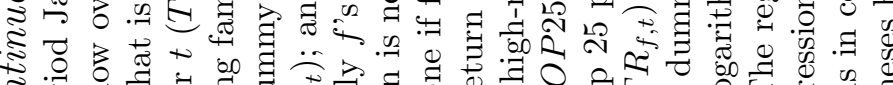

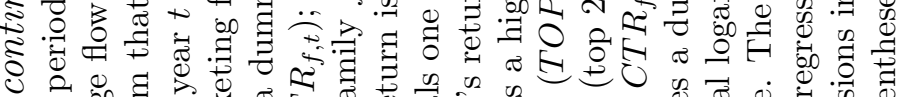

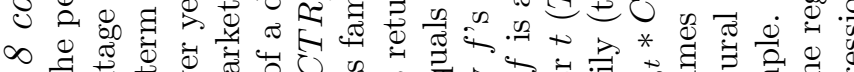

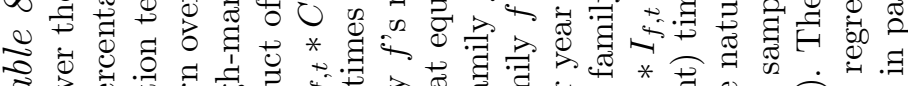

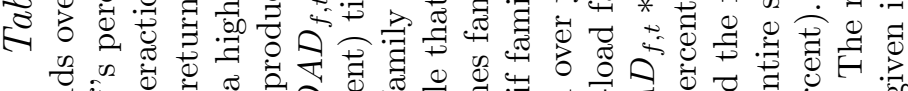

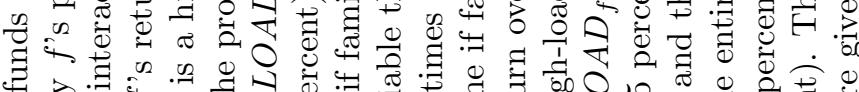

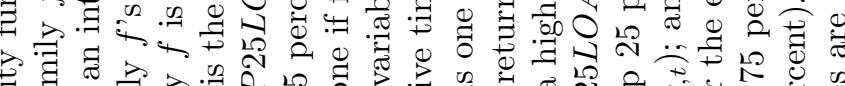

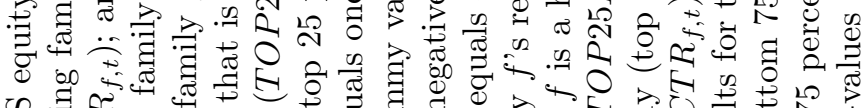

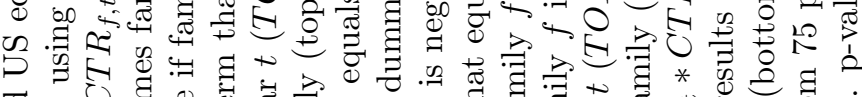

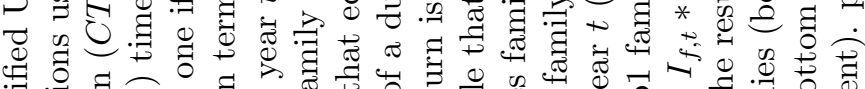

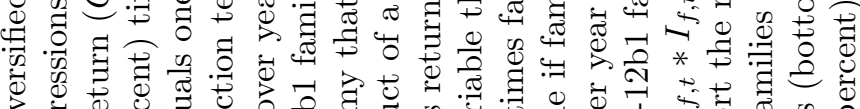

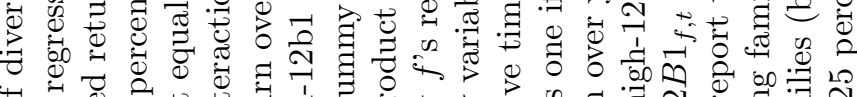

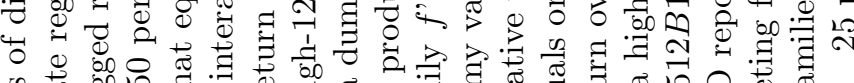

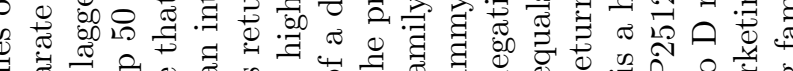

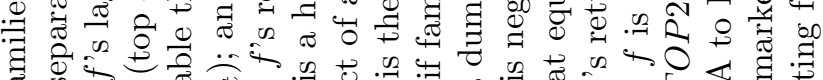

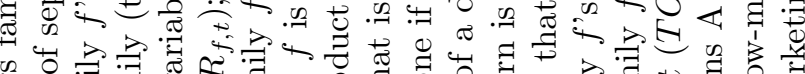
क

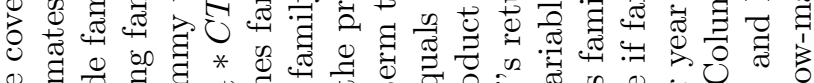

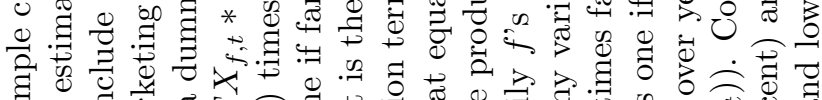

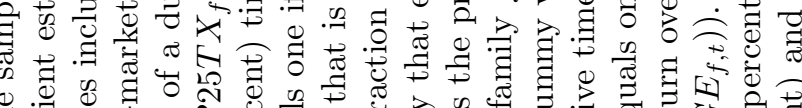

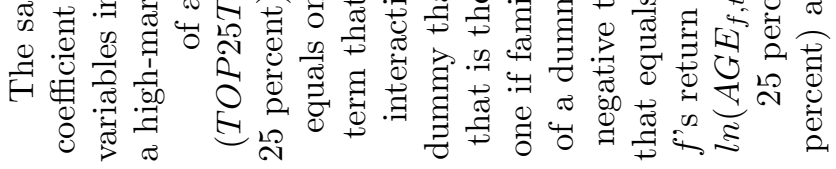


Figure 1: Number of diversified US equity funds.

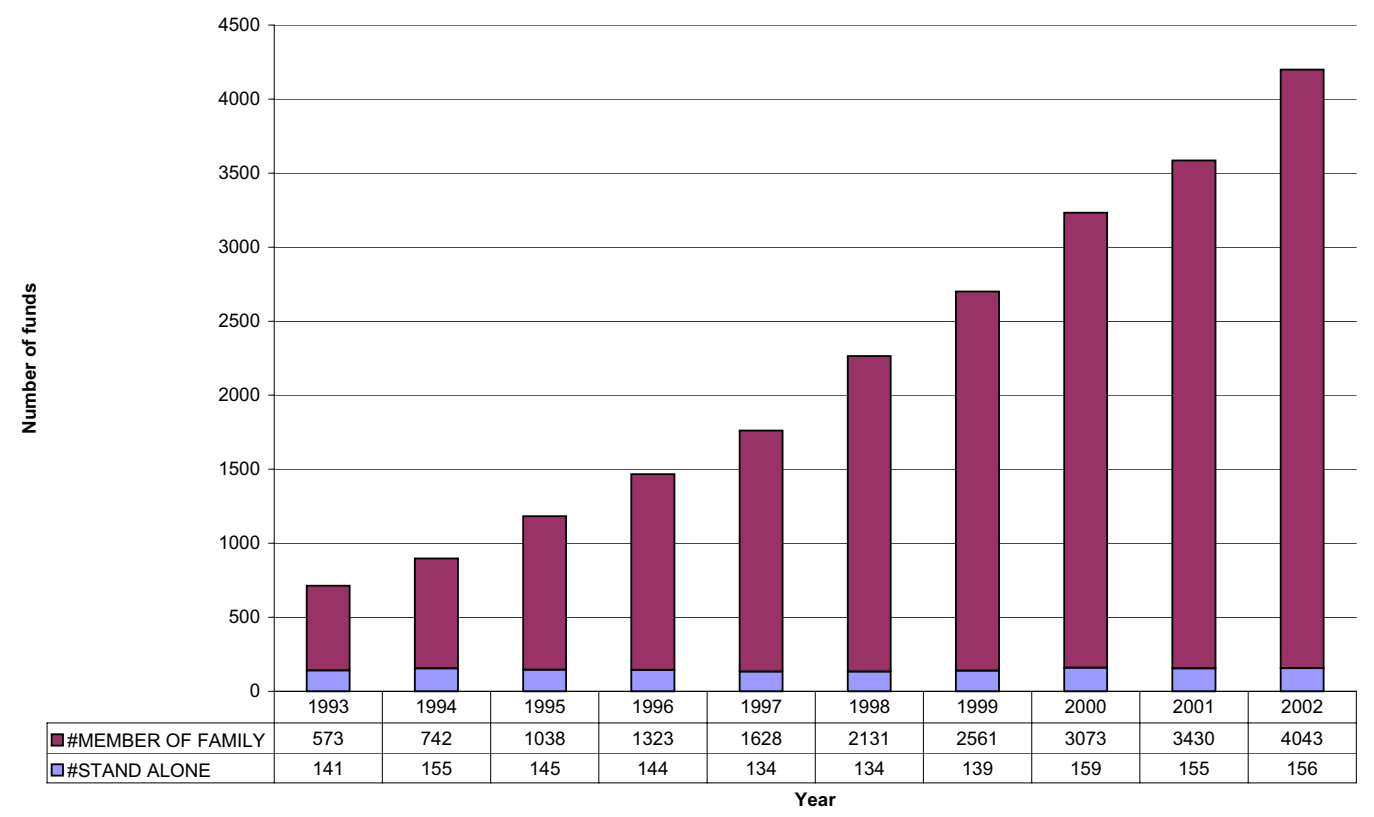

The figure presents a graph with the number of diversified US equity funds in our sample over the period 1993 to 2003. 
Figure 2: Number of fund families and average number of funds per family.

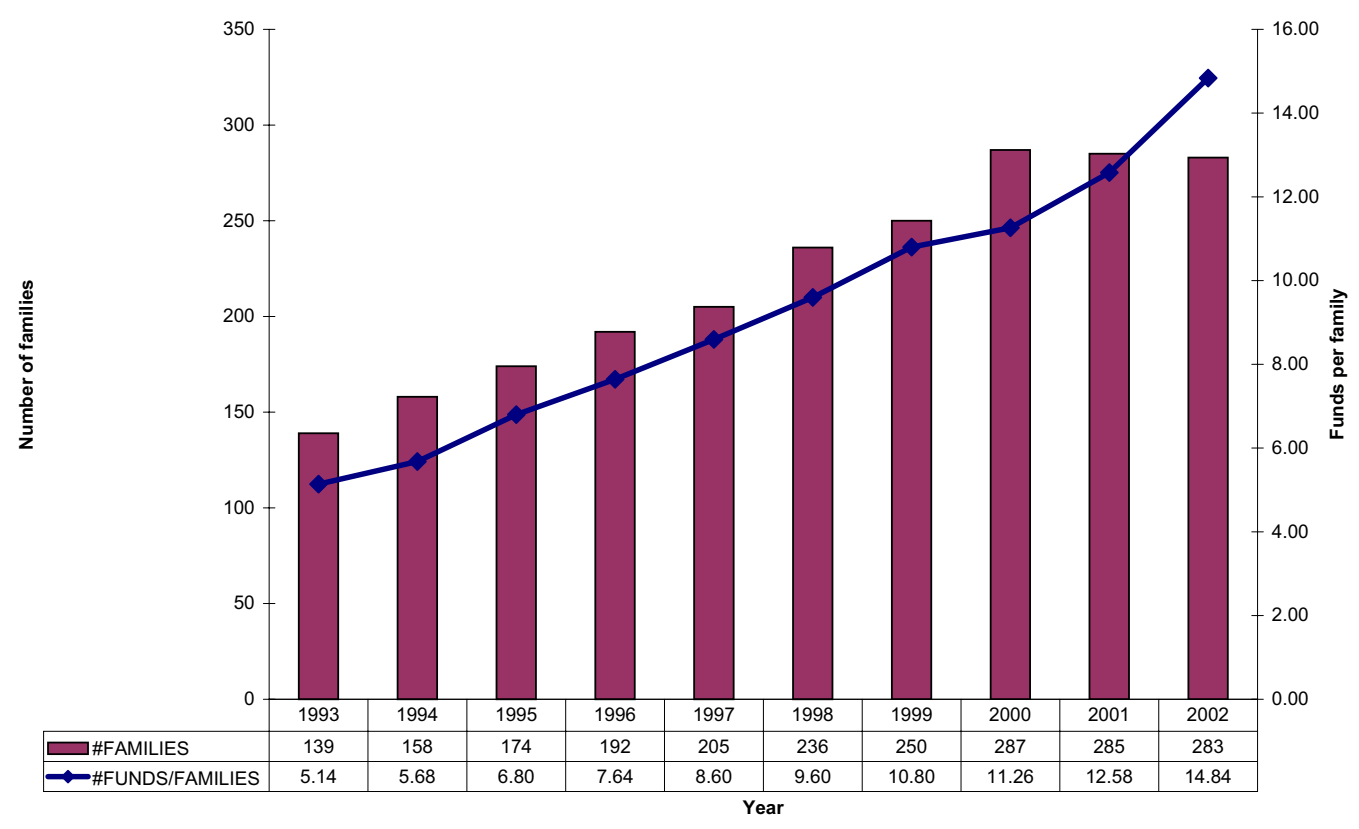

The figure presents a graph with the number of fund families and the number of average funds per family in our sample over the period 1993 to 2003. 
Figure 3: Expenditures on mutual fund marketing.

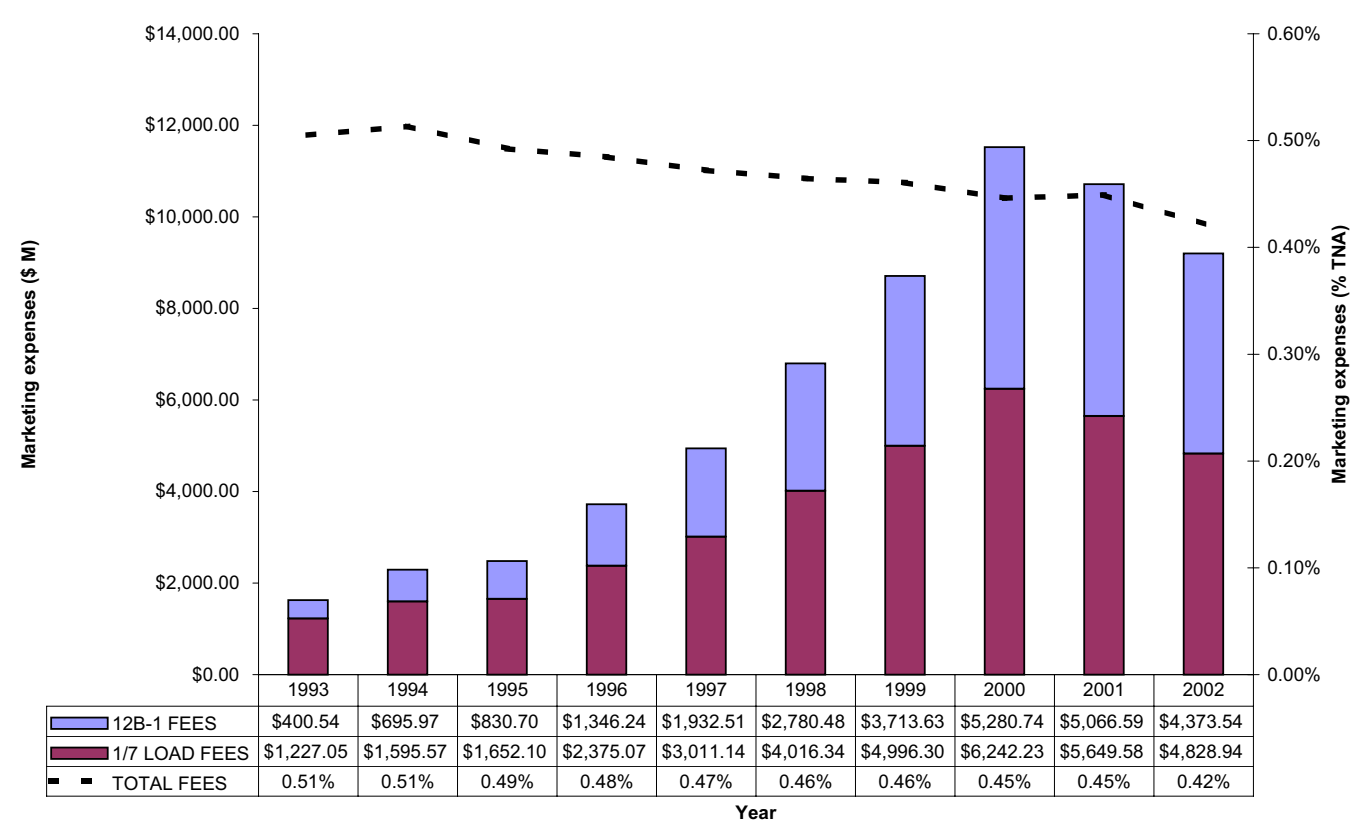

The figure presents an estimate of the dollar amount spent on mutual fund marketing over the period 1993 to 2003. In addition, the graph presents marketing and distribution expenses as a percentage of total net assets under management. 
Figure 4: Flow-performance relation for high- and low-marketing funds.

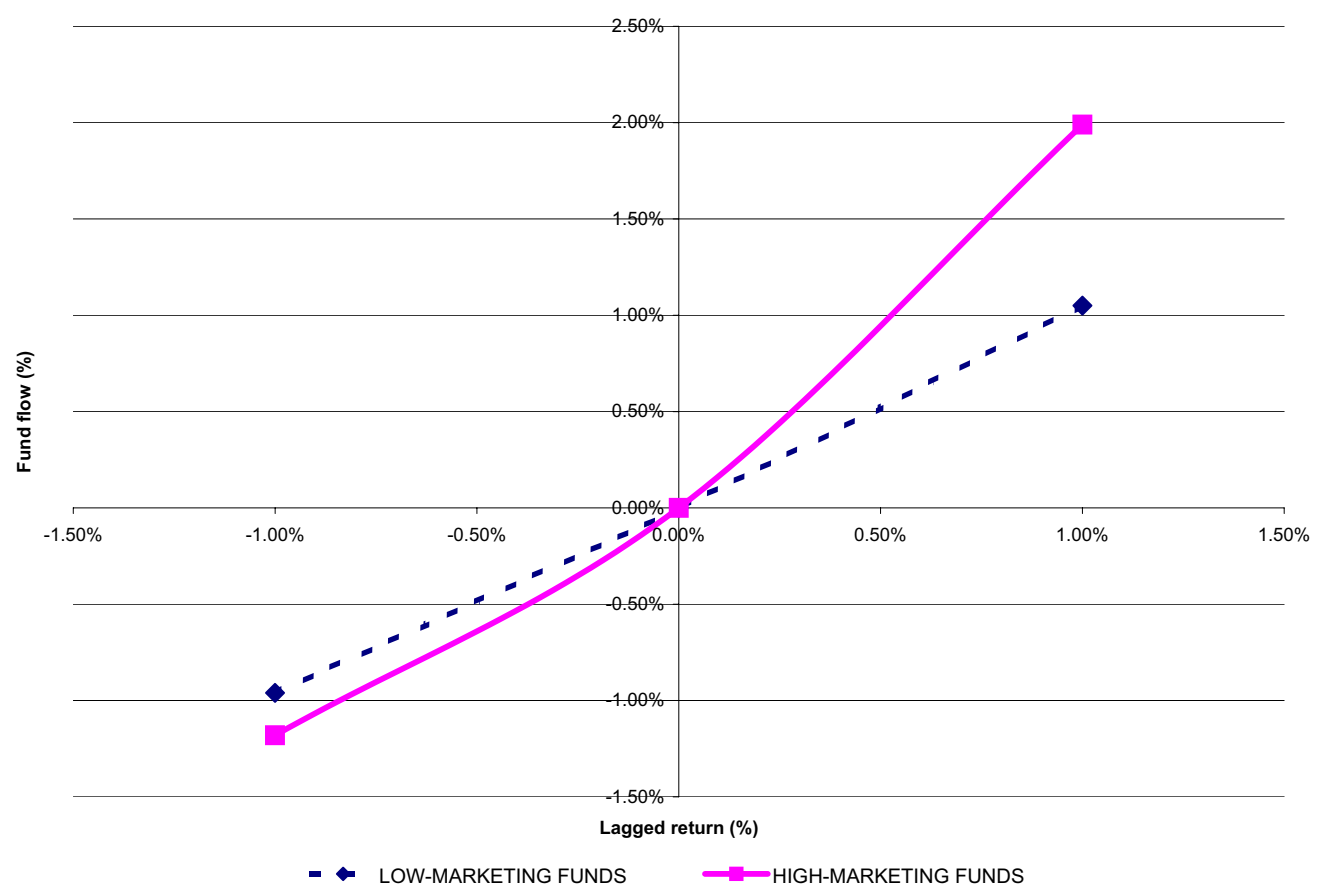

The figure gives a graphical representation of the estimated flow-performance relation for high- and lowmarketing funds. The solid line draws the estimated relation between fund flow and lagged returns for high-marketing funds, and the dashed line draws this relation for low-marketing funds. 